\title{
Pathways to power: Class, hyper-agency and the French corporate elite
}

\author{
Mairi Maclean \\ University of Exeter Business School, Exeter, UK \\ k.m.maclean@exeter.ac.uk \\ Charles Harvey \\ Newcastle University Business School, Newcastle, UK \\ charles.harvey@newcastle.ac.uk \\ Gerhard Kling \\ SOAS, London, UK gk17@soas.ac.uk
}

Published as: Maclean, M., Harvey, C. and Kling, G. (2014). Pathways to power: Class, hyper-agency and the French corporate elite. Organization Studies, 35(6).

Corresponding author: Professor Mairi Maclean, University of Exeter Business School, Streatham Court, Rennes Drive, Exeter EX4 4PU, UK. Email: k.m.maclean@exeter.ac.uk Pathways to power: Class, hyper-agency and the French corporate elite

\begin{abstract}
This paper explores pathways to power from the perspective of the French corporate elite. It compares those who enter the 'field of power' with those who fail to reach this final tier. Adopting an innovative econometric approach, we develop and test three hypotheses. These underline the pivotal role of external networks and the strategic advantage of hyper-agency in maintaining power; and indicate that social origin remains a powerful driver in determining success. Birthright and meritocracy emerge as two competing institutional logics which influence life chances. Higher-status agents benefit from mutual recognition which enhances their likelihood of co-option to the extra-corporate networks that facilitate hyper-agency. The objectification of class-based differences conceals their arbitrary nature while institutionalizing the principles informing stratification. We re-connect class analysis with organizational theory; arguing that social origin exerts an enduring influence on selection dynamics which inform processes of hierarchical reproduction in the corporate elite and society-at-large.
\end{abstract}

\section{Keywords}

Bourdieu, elite careers, field of power, French corporate elite, hyper-agency, institutional logics, social class, social mobility 


\section{Introduction}

Zald and Lounsbury (2010, p. 983) recently called for a re-engagement with key issues concerning elites and their 'strategic command posts' (Mills, 1956, p. 4), focusing on the structures they exploit to extend their influence and agency. Their call echoes the exhortation by Courpasson, Arellano-Gault, Brown and Lounsbury (2008) for organization theorists to address issues relating to the dynamics of status and stratification in society. This paper contributes to research on this important topic. It focuses on the French corporate elite and the pathways pursued by the most powerful amongst them - hyper-agents, the elite within the elite - into what Bourdieu (1993; 1996) terms the 'field of power' (FoP). This is the integrative social domain that transcends individual fields and organizations, serving as a metafield of contestation for dominant agents - individuals holding a controlling position within an organizational field - from different walks of life. We follow Bottomore (1966, p. 14) in defining elites as 'functional, mainly occupational, groups that have high status ... in a society'. This leads us, for the purposes of this study, to identify members of the French corporate elite as the board members of the top 100 French companies.

Extant research, with notable exceptions (Cappelli \& Hamori, 2005; Clegg, Courpasson \& Philips, 2006; Courpasson, 2000; Courpasson \& Clegg, 2006; Hartmann, 2000; 2002; Reed, 2012; Zald \& Lounsbury, 2010), tells us relatively little about the making and activities of hyper-agents whose power and networks extend beyond corporate boundaries into society-at-large (Savage \& Williams, 2008). Studies connecting the lifeworlds of business elites to other worlds in the FoP are rare (Mills, 1956; Useem, 1984). This is regrettable, given the growing importance of elites in contemporary society, as 'state power' recedes in favour of those who run global corporations (Beck, 2008). Given the disproportionate exercise of power by a small number of players, there is a need to investigate further the ‘contemporary dynamics of elite production’ (Clegg et al., 2006, p. 
357). This entails a re-examination of the social struggles which inform stratification (Dudouet \& Grémont, 2007). The role of social origin in determining which individuals come to occupy command posts in business and society is neglected in organization theory (Dezalay, 1995; Scott, 2002). The language of class has lost much of its currency, displaced by rhetoric based on age, gender and ethnicity (Bennett et al., 2009; Bottero, 2004; Skeggs, 2004). Yet the battle to ‘unmask domination’ (Golsorkhi, Leca, Lounsbury \& Ramirez, 2009) demands examining afresh the role of social class in the acquisition and maintenance of power at the highest level (Denord, Lagneau-Ymonet \& Thine, 2011; François, 2010).

It is this research gap that the present paper addresses. In what follows, we develop and test three hypotheses relating to the logic and operation of the FoP, applying advanced statistical modelling techniques to extensive data on French corporate elites. Our objective is to better understand the role of external networks, hyper-agency and social class in determining who becomes an actor in the FoP. The static and dynamic models we develop help explain how a minority of business leaders establish and maintain positions of authority within the FoP (Dezalay, 1995). Others have recognized the importance of dependencies in social networks, such as how appointment as CEO will likely open other doors (Yeo, Pochet \& Alcouffe, 2003); but here we move beyond the limitations of standard single-equation models that fail to capture the complex interrelationships that shape career paths (Useem \& Karabel, 1986). Rather, we incorporate the inherent endogeneity of career pathways through application of a generalised linear model, differentiating between variables of fate, given at birth and outside agents' control, and variables of choice, where actions and attitudes matter. This approach enables us to identify more precisely direct and indirect relationships between critical variables, and to test more robustly the three hypotheses we advance.

In the following section, we review the literature on French elites and establish the context of our research. We then elaborate Bourdieu's concept of the FoP in terms of purpose, 
modus operandi and domination by hyper-agents, explaining how this fits within his framework of capital and field theory. The three hypotheses around which the paper is framed are then articulated and explained. Details of our sources and methods follow before testing of hypotheses and presentation of our findings. The enduring importance of social class as a master variable is highlighted, establishing the focus for theorization in our discussion and conclusion.

\section{The French Corporate Elite}

It is some time since Lévy-Leboyer (1979, p. 181, cited in François, 2010, p. 11) predicted the 'equalization of conditions of access to the business elite'. ${ }^{1}$ Yet neither mass education nor three decades of globalization have undermined the French corporate elite's grip on power. Power-brokers require ‘a solid baggage of expertise’ (Dezalay, 1995, p. 342), but the meritocratic ethos of the French Republic is at odds with the 'elitist conceptualization of power’ which prevails (Genieys, 2005, p. 414); resulting in on-going tensions between 'nostalgia for the ruling class... unified by a bloc of traditions and internal alliances, and the promise of a permanent democratic openness, the justification of any Republican meritocracy’ (Charle, 1987, p. 455). Bourdieu (1996) contends that education reinforces existing social structures by strengthening disparities in culture, status and wealth. The outward appearance of equal opportunity, however, is sustained by the notion of a 'meritocratic society which rewards effort and ... selects the best' (Pinçon \& Pinçon-Charlot, 2007, p. 103). Elite training has become the preserve of the grandes écoles, which foster 'the belief of the dominant class in their own legitimacy and ... the belief of the other classes in that legitimacy’ (Wacquant, 1993, p. 39). The Ecole Polytechnique was founded in 1794 by revolutionaries who failed to anticipate the 'entrenchment' of French elites along class lines 
(Suleiman, 1978). The Ecole Nationale d'Administration (ENA), France's most prestigious grande école, was established in 1945 following the discrediting of the old elite, yet serves as a 'machine for classifying people' (Suleiman, 1997, p. 21). Tradition, combined with the rigidity of the examination structure, has militated against its professed democratization (Bourdieu \& Saint-Martin, 1973); its student body remaining predominantly upper-middle class (Suleiman, 1997).

Viewed in this light, birth and meritocracy appear as two competing society-level or institutional logics; the espoused Republican logic of egalitarianism and meritocracy at variance with the underlying but dominant logic of elitism and heredity (Argyris, 1977; Charle, 1987). According to Thornton and Ocasio (1999), power in organizations is influenced by higher-order logics which prevail in society-at-large (Davis \& Greve, 1997). Institutional logics 'define the norms, values, and beliefs that structure the cognition of actors in organizations and provide a collective understanding of how strategic interests... are formulated' (Thornton, 2002, p. 82). The two competing logics of birthright and meritocracy are reflected in our study by variables of fate and variables of choice respectively.

The French corporate elite are presented in the literature as relatively unified, characterized by dense, cohesive networks (Wagner, 2010). This derives partly from the 'strong and homogenous bureaucratic training’ imparted by the grandes écoles (Genieys, 2005, p. 419; Suleiman, 1978), inculcating similar 'ways of seeing, feeling, thinking and acting' (Eymeri, 2001, p. 824). This shared habitus may be reinforced further by membership of a grand corps (Boltanski, 1973; Hartmann, 2000), the pinnacle of France's civil service elite, functioning as extended families (Dudouet \& Joly, 2010; Suleiman, 1978). The business elite comprise a small world characterized by high levels of social closure (Boltanski, 1973; Davis, Yoo \& Baker, 2003). Denord et al. (2011, p. 37) highlight the 'very strong social endogamy' of French directors: a social group 'particularly closed in on itself' (Comet \& 
Finez, 2010, pp. 9-10). Those achieving membership of the exclusive Club du Siècle, the epitome of privilege, are reputedly characterized by a 'unity of type, uniformity of age, monotony of scholarly diplomas, homogeneity of origins and conformity of class' (Denord et al., 2011, p. 56; Kadushin, 1995). This small world effect has been heightened traditionally by the prevalence of interlocking directorships, ties which bind the business system together; although recent governance initiatives have led to their partial dilution (Maclean, 2002). Family networks are pivotal in France (Bauer \& Bertin-Mourot, 1997); and the business world has woven strong ties with the State, which serves as a lynchpin (Hartmann, 2011).

Prior research has shown how power is unevenly distributed between central and more marginalized dominant agents in France (Comet \& Finez, 2010). One of our objectives in this paper is to explain why this is so.

\section{The Field of Power}

The work of Bourdieu has aroused considerable interest in organization science (Anheier, Gerhards \& Romo, 1995; Golsorkhi et al., 2009; Kerr \& Robinson, 2012; Oakes, Townley \& Cooper, 1998). His ‘master concepts’ of capital (economic, cultural, social and symbolic resources), field (social spaces of objective relations between positions) and habitus (internalized dispositions) have attracted much attention. He is less well known, conversely, for his analysis of class structure in general, and of hierarchy and domination in particular. His concept of the FoP remains under-utilized, despite its theoretical and empirical potential (Bourdieu, 1993; 1996). The present paper presents an opportunity to explore this latter aspect of his work.

For Bourdieu, power is relationally embedded. He conceives of the FoP as 'a field of forces structurally determined by the state of relations of power among different forms of power, or different forms of capital’ (Bourdieu, 1996, p. 264). Capital is a social relation, a 
generalized resource denoting a 'power over the field' (Bourdieu, 1985, p. 724). Domination within any field is contingent on possessing the right quantities and combinations of economic, cultural, social and symbolic capital. Economic capital is the overriding differentiator, since conventional wealth may ultimately be converted into other forms of capital. Cultural capital, denoting familiarity of the arts and culture as well as scientific knowledge, is gained through formal education and informal assimilation, objectified as qualifications, and more readily available to offspring of the well-to-do classes. The progeny of the better-off similarly have access through family and friends to social capital, a dense network of relationships and reciprocal obligations pivotal to career advancement and social advantage (Le Wita, 1994). Symbolic capital, in the form of honours and titles, desirable goods, privileged pursuits and memberships, legitimizes the domination of elite agents through institutional consecration (Bourdieu, 2011, p. 129). Capital formation is an on-going, dynamic process, subject to accumulation or attrition. It fortifies social distinctions, social processes being driven by struggles waged implicitly between different classes and class fractions. While 'all positions of arrival are not equally probable for all starting points' (Bourdieu, 1986, p. 110), the expertise of individual agents in playing the hand they are dealt influences the outcomes of ensuing struggles in the FoP. Bourdieu illustrates this point in The Field of Cultural Production (1993), populating a fictitious FoP with the panoply of heirs and arrivistes featured in Flaubert's novel Sentimental Education. The aces they hold are 'the inherited assets which define the possibilities inherent in the field' (Bourdieu, 1993, p. 150). However, the characters must still play the game skilfully to succeed (Bourdieu, 1996). In the hierarchy of fields and subfields which obtains, the corporate field is ascendant, its distinguished representatives aligning with the FoP's most elevated positions (Bourdieu, 1996, p. 269). This is partly due to the nature of its field-specific capital. Bourdieu (2011, p. 128) distinguishes between the possession of capital per se and that of capital granting power 
over different forms of capital. For Bourdieu (1986), the specific logic of a field dictates which capitals hold sway within it. What sets the organizational field apart above all is the potential of its field-specific capital (predominately economic as well as cultural) for accumulation and convertibility into other resources, assets and forms of power, potentially resulting in the accrual of a sufficient quantity of capital to dominate the field (Bourdieu, 2011; Savage, Warde \& Devine, 2005). This gives the uppermost echelons of the corporate field a particular affinity with the ruling class, 'the collection of agents who occupy de facto positions of power over capital' (Bourdieu, 2011, p. 128). Corporate heads, by virtue of their privileged positioning within the organizational field, occupy as if by right a distinctive place in French society among the ruling elite (Bourdieu, 2011, p. 136; Savage et al., 2013). As Bourdieu (1996, p. 335) explains:

'Few ruling groups have ever brought together so many principles of legitimation of such diversity, which, although apparently contradictory (such as the aristocratism of birth and the meritocratism of academic success...), combine to inspire in the new leaders the most absolute certainty in their legitimacy'.

That the principles of legitimation upon which their success rests derive from the competing logics of meritocracy and birthright enhances their power and status. The corporate elite’s belief in its own legitimacy stems from its capacity 'to impose on the dominated the recognition of its domination, that is to say, the misrecognition of the arbitrary nature of its power' (Bourdieu, 2011, p. 139). Making the arbitrary appear destined, decreed by fate, blurs the boundaries between logics of fate and choice, such that agents 'feel "made” for jobs that are “made” for them’ (Bourdieu, 1986, p. 110).

The reproduction of oligarchies is effected through the interplay of individual agency in conjunction with the instruments and institutions of consecration. The latter include the grandes écoles and grands corps, whose shared function is to reproduce a system which manages the elite's internal divisions by classifying the 'dominated and dominant fractions of 
the dominant class' (Bourdieu, 1993, p. 101), mirroring processes within the FoP. Individual agency is critical. Careers, particularly those of dominant agents, extend beyond the confines of organizations, connecting struggles within the organization with wider societal conflicts (Geletkanycz \& Hambrick, 1997; O’Mahony \& Bechky, 2008). So while organizational fields are sites of contestation, where agents are defined as dominant or subordinate according to their location in the field (Iellatchitch, Mayrhofer \& Meyer, 2003), the FoP serves as a 'macro-level arena of struggle across a range of power fields' (Swartz, 2008, p. 50). Here, the most dominant agents from different fields like health, politics, law, culture and the media are pitted against each other (Dezalay, 1995; Wacquant, 1993). These trials of strength in the FoP are not a smooth process, as agents occupying different positions and possessing different types and volumes of capital jostle for dominance. Yet the FoP also creates the structural conditions for agents to make common cause by forming (temporary) issue-based coalitions of interests, turning competition and contestation into collusion (O’Mahony \& Bechky, 2008). Shared class-based interests promote collaboration in the FoP, reinforcing the contours of the corporate elite as a class within the ruling class, to which it shares particular homologies (Bourdieu, 2011). Power has been defined elsewhere as ‘command over resources’ (Maclean, Harvey \& Press, 2006; Maclean, Harvey \& Chia, 2010). Here, we extend this definition to embrace as a key resource the power of elite occupants of command posts to assemble diverse groups of high-status actors to make common cause. Lindsay (2008, p. 62) calls this a form of 'convening power', which he identifies as one of the most compelling resources at the disposal of elites, through which they 'impose strategic orientations’ (François, 2010, p. 7). Notably, a resource must be maintained to retain its capacity to be exercised. Elites must therefore preserve their legitimate right to convene power by retaining place and remaining active within the FoP (Courpasson \& Golsorkhi, 2009). 
Through alliances and networks, elite agents operating within the FoP seek to influence societal decision-making processes, resource flows, opinion formation and wider logics of action by winning commitment to agreed objectives. They battle to impose their values and appropriate positions of power (Bourdieu, 2011). Sustained by public perceptions of their civic-mindedness, they become the purveyors of legitimizing narratives designed to shape collective systems of meaning (Giddens, 1984; Lounsbury \& Glynn, 2001). Agents seek to direct agendas while influencing their own positioning within social space; the boundary between those who belong and those who do not, inclusion and exclusion, being continually contested and redrawn (Bourdieu, 1993).

Combatants, however, do not merely challenge for a place in the FoP. In claiming the 'right' to discourse, the most powerful compete to determine the nature of the FoP itself. What is at stake is 'a redefinition ... of a whole series of pecking orders' (Dezalay, 1995, p. 336). Contestants struggle to impose 'the species of capital which gives the upper hand in the field of power, and ... across all of society’ (Wacquant, 1993, p. 25). In doing so, some force action through legislative or quasi-legislative means, shaping the regulatory and fiscal landscape in their favour, depending on their interests (François, 2010). Hyper-agency can be deployed to preserve the status quo; it also creates the possibility to re-order the rules of the game and reset the system - to contest the right to 'dictate the dominant principle of domination’ (Bourdieu, 1996, p. 265).

\section{Development of Hypotheses}

Our statistical models, one static, the other dynamic, test three implications of the FoP: (1) networks outside the corporate sphere are crucial in enhancing and sustaining power (defined by positions); (2) hyper-agents are more successful in extending their influence and retaining 
power; (3) social class is the critical 'control variable' in determining which agents enter and maintain positions of influence within the FoP.

Extant literature emphasizes the value of bridge-building relationships beyond company boundaries in bolstering power (Coignard \& Guichard, 2000; Collins-Dogrul, 2012; Geletkanycz \& Hambrick, 1997; Scott, 1991). The external activities of directors increase their value to their organizations, but also work to their personal advantage (Useem, 1984). Burt, Hogarth and Michaud (2000, p. 141) found that successful French executives benefited from networks rich in 'structural holes', enhancing their ability to attract resources, which 'flow disproportionately to people who provide indirect connections between otherwise disconnected groups'. Collins-Dogrul (2012) concurs, arguing that brokers reap rewards by bringing together previously disconnected actors and helping to sustain these relationships. These analyses support Granovetter's (1974, p. 52) assertion that the acquisition of power is influenced by the 'strategic location of a person's contacts'. However, these accounts do not tell us enough about how an agent's positioning within a web of external networks might facilitate their attainment of top-tier positions (Stern \& Westphal, 2010), particularly in the cultural context of the French corporate elite (Denord et al., 2011; François, 2010; Pinçon \& Pinçon-Charlot, 1998). Hence, we state:

Hypothesis 1: Networks beyond company boundaries determine an agent's power in terms of achieving top executive and non-executive positions.

Prior literature likewise suggests that hyper-agents who pursue multiple career pathways strengthen their overall position (Davis et al., 2003; Hamdouch, 1989; O’Mahony \& Bechky, 2008). A study of 84 French CEOs conducted by Bauer and Bertin-Mourot (1997) found that the longest-serving were those in highly networked companies, suggesting a connection between career longevity and corporate networking. The boundary-spanning 
activities of hyper-agents provide a bridge between corporations and not-for-profit organizations, serving as ‘conduits for social influence’ (Geletkanycz \& Hambrick, 1997, p. 657). These enable them to 'exert disproportionate influence' over the governance of both companies and society-at-large (Stern \& Westphal, 2010, p. 280). Schervish (2003), for example, observes that hyper-agents active in philanthropy enjoy an increasingly extensive policy-making and agenda-setting role, becoming 'nodal actors’ (Ball, 2008, p. 749). Philanthropy confers legitimacy and increases voice, so amplifying their potential to determine outcomes in other fields (Brown, 1994). However, the literature tells us little about how pursuing multiple pathways might help maintain a position within the FoP through the cultivation of diverse channels of influence. Thus, we propose:

Hypothesis 2: Being a hyper-agent is the best strategy to retain place within the FoP. Agents restricted to one pathway are less likely to retain power.

Palmer and Barber (2001) argue that embeddedness in prized organizational and social networks is a manifestation of the class system (Bond, 2012; Kadushin, 1995; Mills, 1956). The implication is that agents who suffer social status marginality find it more difficult to penetrate the 'inner group' of corporate directors active in the FoP. Westphal and Zajac (1995) stress the importance of demographic similarity in director selection. For Stern and Westphal (2010), an agent's capacity to secure board appointments is regulated by ingratiating influence behaviour deriving primarily from class background. Those from higher-status backgrounds are found to have greater interpersonal appeal than their less privileged rivals.

However, class cultures have changed in recent decades, becoming more individualized and implicit (Bennett et al., 2009; Bottero, 2004; Gunz, Mayrhofer \& Tolbert, 2011). Class differences have been obscured through their ostensible replacement by an expanded middle class. In this, social scientists, including organization theorists, have been to 
some degree complicit by tacitly going along with the censoring of class analysis by ‘democratic creed' (Charle, 1987, p. 11) and favouring neo-liberal ideology that class no longer matters, having forfeited its potential to determine life chances and career outcomes (Pinçon \& Pinçon-Charlot, 2007). Clegg (1989, p. 3) points to the lack of 'effective interchange' between class analysis and organizational analysis, which have become disconnected. As Boltanski and Chiapello (2007) observe, the displacement of social class from the centre of European sociology occurred just when new dimensions of inequality were arising (Godechot, 2011). Bourdieu (1998) agrees with Boltanski (1982, p. 305) that it is fallacious to assume French society has been transformed into a 'society of the middle classes'. The advent of a seemingly classless society has prevented closer scrutiny of intraclass differences, diverting attention from social processes driven by class and social stratification. Elites have been largely absent from class analysis (Savage et al., 2013), while the internal differentiation within social classes, 'the secondary differences which, within each of the classes...separate class fractions', are rarely examined in the literature (Bourdieu, 1986, p. 114; Flemmen, 2012). The prominence of the corporate class, positioned at the apex of the organizational field and into which some from the lower orders have gained admission, serves paradoxically to mask intra-group class differences.

Bourdieu (1987; 1998) did not seek to conduct a systematic social class analysis (Savage et al., 2005). However, his project aims precisely to unveil the mechanisms of domination which remain hidden from view (Boltanski \& Chiapello, 2007), revealing the implicit processes of social closure which foster and disguise inequality (Bottero, 2004). In Bourdieu's (1998) view, to refute the existence of class is to deny the continuing principles of differentiation in society. His work has helped revitalize class analysis by drawing attention to the ways in which taste, culture and symbolic goods inform the reproduction of economic and social hierarchies (Pinçon \& Pinçon-Charlot, 2002; Savage et al., 2013). For Bourdieu 
(1986, p. 101), life chances are objectively inscribed in the volume and composition of an individual's capital. Social class is internalized as 'class habitus', conditioning behaviour and influencing the acquisition of an elevated status and positioning (or not). Detailed studies of the continuing role of social class in shaping the French corporate elite supported by extensive empirical data are lacking (Dezalay, 1995; Pinçon \& Pinçon-Charlot, 1998). The literature has not articulated fully the extent to which social class forces still exert a tangible impact on career success at this level, with implications for attendant power differentials. The material effect of social class on an agent's 'trajectory in social space', in terms of career progression and durability in the FoP, may be far-reaching despite its seeming invisibility (Bourdieu, 1987, p. 4; McLeod, O’Donohoe \& Townley, 2009). Hence, we propose:

Hypothesis 3: Social class serves as the 'master variable' in determining an agent's entry into and continuation within the FoP.

If our findings confirm the first two hypotheses, this would support the theoretical construction of the FoP as a social space structured by network interactions and dominated by hyper-agents. The third hypothesis suggests that social class serves as an underlying control variable that privileges those from higher-status backgrounds and curbs access to the FoP.

\section{Methodology}

\section{Identifying corporate actors in the FoP}

Our study is based upon personal and career profiles of 1160 members of the French corporate elite: those serving as main board members, executives and non-executives (excepting employee representatives), of at least one of France's top 100 largest companies on 1 January 1998. We detail the social origins, education, honours, corporate and extracorporate networks of all 1160 directors, focusing on their career trajectories between 
1998 and 2004 . We identify 386 of the 1160 individuals profiled, approximately one third, as hyper-agents: multi-positional actors within the FoP (Boltanski, 1973; Bourdieu, 1996).

Business leaders qualifying as hyper-agents satisfy at least two of four criteria: (i) appointment as a top-tier executive ( $\left.y_{1}\right)$, CEO or Executive Chairman of a top 100 company, including those styled Président Directeur-Général (PDG) and Président du Directoire; (ii) a corporate networker $\left(y_{2}\right)$ defined as holding at least two board memberships of top 100 French companies, or one top 100 company and at least two directorships of other large companies; (iii) an extra-corporate networker ( $\left.y_{3}\right)$ designated by membership of two or more national or international non-business boards; (iv) an entrepreneur $\left(y_{4}\right)$ with significant ownership rights at 25\% or more of equity (Franks \& Mayer, 1997). Application of the four differentiating criteria effectively divides the French corporate elite into two categories, those who become power-brokers at societal level (33\%), and those whose careers are more confined to business (67\%) (Comet \& Finez, 2010).

This method of identifying members of the business elite active within the FoP recognizes that those holding high office in business have different power bases, and affirms that those with more than one power base are most likely to function effectively at a societal level (Boltanski, 1973). The four individual pathways $\left(y_{1}, y_{2}, y_{3}, y_{4}\right)$ embrace different dimensions of power, capturing the definition of power as 'command over resources' in terms of corporate control and ownership ( $y_{1}$ and $y_{4}$ ), while reflecting other dimensions of power, external networks and the power to convene ( $y_{2}$ and $\left.y_{3}\right)$ (Lindsay, 2008).

Naturally, the number of individuals identified as active within the FoP is dependent upon definitions and entry criteria. Requiring a minimum of two pathways is consistent with the literature (Bourdieu, 1996; Burt et al., 2000; Hjellbrekke et al., 2007), and identifies an exclusive group of 386 people. Raising the bar to three pathways would be overly restrictive in reducing the number qualifying to 128 . This would exclude, inter alia, Jacques de 
Larosière de Champfeu (former Head of the IMF), which seems unreasonable. Including more companies or relaxing the definitions for corporate or extra-corporate networker would have the opposite effect, but would be inconsistent with what is known already about the high concentration of power in elite corporate circles (Maclean et al., 2010).

\section{Conceptual framework}

Any two or more of the four individual pathways can be combined, and thus there are ten observed modes of entry into the FoP. These combined pathways are interdependent. Top-tier directors, for example, are more likely to be singled out for appointment to other corporate and non-corporate boards. Moreover, variables of choice like education may be influenced by exogenous factors like social class and gender, which we call variables of fate, given at birth and determined outside the model. Both types of variables, choice and fate, can influence pathways to power, as expressed in Figure 1.

\section{[FIGURE 1 HERE]}

\section{Method of sampling, data collection and coding}

The top 100 French companies were identified by computing an equally-weighted composite measure of size based on total capital employed, turnover, profit-before-tax, and employment (Grant, 1997). Following Zajac and Westphal (1996), the seven-year study period was deemed sufficiently long to model dynamic effects within the FoP such as transitions between career pathways and survival rates. ${ }^{2}$ To profile individual members of the elite, data were gathered from five main sources: company annual reports; Le Guide des Etats Majors; Who's Who in France; extensive web searches, including company websites, Business Week, Forbes and the Financial Times; newspaper and periodical articles. Two of the authors coded the dataset, debating and reconciling difficult cases as necessary, including any partly subjective judgements such as parental social class, to ensure agreement. 


\section{Definition and construction of variables}

Following Halsey (1995), a four-way classification was adopted for social class: upper, upper-middle, lower-middle, and lower class. Classification was undertaken mainly on the basis of parental occupation (Bourdieu, 1987; Denord et al., 2011); supplemented by information on schooling, place of upbringing, and family circumstances. Upper class (1) was reserved for those whose parents held a leading position in society or owned sizeable $(\geq 1 \%)$ equity stakes in top French companies. Upper-middle class (2) was applied to top professionals including lawyers, doctors, engineers, senior state officials, and senior business people. Lower-middle class (3) was applied to white-collar occupations including teachers, sales people, lesser officials and technicians; while lower class (4) was reserved for parental occupations like worker, miner and van driver.

Birthplace was coded as falling into one of eight French regions, with additional categories for those born in a French colony or abroad. Educational data were coded by attendance (or not) at an elite school and attendance (or not) at one or more elite higher education (HE) institution. Many individuals attended more than one secondary school, with substantial numbers educated locally before preparing for competitive examinations (in classes préparatoires) for entry into elite HE institutions. Top academic and professional qualifications by level and type were recorded. Data on state honours were gathered for the Légion d'Honneur (LdH) and the Ordre National du Mérite (ONM), which share the same ranking system and had similar frequencies in 2002: chevaliers (77\%, 79\%), officiers (19\%, $17 \%)$, commandeurs (3\%, 3\%), grands officiers $(0.95 \%, 0.92)$, and grand-croix $(0.05 \%$, 0.08\%). Membership of a grand corps is, as mentioned, a signifier of inclusion at the highest level within the French civic elite. Foremost among these are the Inspection des Finances and the Corps des Mines (Bourdieu, 1996; Suleiman, 1997). Known membership data were also gathered for the Conseil d'Etat, Cour des Comptes, and the Corps des Ponts et Chaussées. 
Individuals were classified according to career type: those who spend their careers wholly or primarily in the private sector; those who began their careers within government departments before entering business; and those who began in a profession before entering the corporate sector. The number of top 100 company main board memberships and non-top 100 main board memberships held by an individual in 1998 and 2004 are recorded, but subsidiary board memberships are excluded. Non-top 100 French companies are included if classified as large companies by inclusion in Le Guide des Etats Majors. Given our interest in the FoP, the specific nature of the power base in which each director is practically rooted was recorded, including academia, banking and finance, law, the corporate sector, family trusts, and the State. Likewise, the type and extent of engagement in external networks is noted, including involvement in charities, public bodies, business organizations, higher education, sports and culture. Overall network size is captured by the total number of corporate and extra-corporate board memberships. Further details of variables, definitions and coding scheme are provided in the Appendix.

\section{Empirical Analysis}

\section{Entering the FoP}

In Table 1, we summarize our findings on discrete and multiple pathways to power. Part A relates to entry qualifications. Of the 1160 elite members, 17\% qualified as top-tier executives of a top 100 French company $\left(y_{1}\right)$. Nearly all (91\%) entered the FoP. Those qualifying as corporate networkers $\left(y_{2}\right)$ were more numerous (32\% of cohort), $84 \%$ gaining admission to the FoP. An even larger number (48\%) qualified as extra-corporate networkers (y3), but only $68 \%$ entered the FoP. The smallest number (4.5\%) qualified by having significant ownership (y4) rights in large companies, of whom $90 \%$ entered the FoP.

In Part B of the table, frequencies are displayed in rank order for the ten pathway combinations pursued by those active within the FoP at the core of the French business elite. 
The largest group (47\%) are senior executives beneath the rank of CEO in large companies with extensive networks within and beyond business: the corporate and extra-corporate networkers who unite the system by prosecuting the agendas of the most powerful agents, the top-tier executives and owner-executives who combine three or four pathways. The most numerous (24\%) are top-tier corporate and extra-corporate networkers who lead large companies and serve as board members of other companies and organizations outside the corporate sector. In terms of power, these individuals are rivalled only by the 15 (4\%) top-tier owner corporate and extra-corporate networkers who bestride the FoP in France. Interestingly, a large minority of top-tier executives and business owners do not serve as corporate networkers, preferring to channel their energies within their own companies and build extra-corporate networks.

\section{[TABLE 1 HERE]}

The emerging picture of the FoP is one of a small population of highly networked hyper-agents, composed of executives and non-executives, who connect the most important business and non-business organizations in France. Of their number, the top-tier corporate executives and owner-executives are pre-eminent. Our task in what follows is to identify and explain the factors that elevate them to positions of such authority.

\section{Descriptive findings}

Table 2 provides descriptive statistics for all variables and reveals considerable variation within the sample. For example, attendance at an elite school (56\%) is far from ubiquitous, and award of a state honour proves exceptional rather than commonplace, and therefore is not an 'entrance ticket' to the FoP. Nevertheless, there is homogeneity with respect to nationality (90\% French) and gender (96\% male), underlining the importance of national processes for reproducing elites (Hartmann, 2011), and confirming the 'very slow progress of parity' (Dudouet \& Joly, 2010, p. 40). 
[TABLE 2 HERE]

By dividing the sample into those active (386) and not active (774) within the FoP, significant differences are detectable using multivariate analysis of variance (MANOVA). Table 3 reports on differences between the two groups overall (All) and variable-by-variable based on the Wilks' lamda test statistic. The overall test (All) exhibits a p-value of 0.000 , which indicates that the two groups are dissimilar, even though distinct differences exist for just a few variables such as grand corps and nationality. Counter-intuitively, entering the FoP does not seem primarily to be related to differences in education nor, at first sight, to depend on social class. However, descriptive statistics cannot reveal the inherent interdependence between pathways to power; the alleged endogeneity of the variables of choice necessitating closer scrutiny.

[TABLE 3 HERE]

\section{Endogeneity: choice or fate?}

In contrast to prior social network research (Coignard \& Guichard, 2000; François, 2010; Scott, 1991), our interest lies in modelling the inherent endogeneity between socio-economic variables. Education, for example, while commonly perceived to be critical in determining social outcomes, is not an exogenous variable because attendance at an elite school may in turn be related to social class, gender or birthplace. Exogenous variables like age and social class, conversely, are determined outside our model and taken as 'fallen from heaven'. In developing our statistical models (static and dynamic), it is therefore necessary to identify those variables affected by endogeneity. There are two main issues. First, the likely interrelationship between variables of fate and choice might cause multicollinearity. In this case, however, the computed variance inflation factors (VIF) peak at 1.64 ( $p b \_f t$ ), which is beneath the critical level of five, indicating that multicollinearity is not a concern. Second, it 
is possible that any model might suffer from an endogeneity bias, since operating in the FoP or pursuing a certain pathway affects variables of choice.

Our aim is to identify the true underlying factors that help secure and maintain a position in the FoP; so understanding the impact of variables of fate on education and other variables is crucial, since 'the requiring of a given diploma can be a way of demanding a particular social origin’ (Bourdieu, 1986, p. 102). Accordingly, we ran two types of models to measure the impact of variables of fate $(\mathbf{z})$ on variables of choice $(\mathbf{x})$. As variables of choice are binary, we apply logit models estimated using Maximum-Likelihood (Greene, 2008). Table 4 shows the results of logit models for all variables of choice using the pseudo Rsquared to indicate overall model fit applying a threshold of $25 \%$. Our second measure, the area under the receiver operating characteristic curve (ROC), provides an indication of the accuracy of logit models. If the ROC statistic exceeds 0.8 , the model prediction is accurate, implying that fate explains the particular variable of choice. Both measures point to the same variables exhibiting a high degree of dependence on variables of fate. In particular, elite schooling (pseudo $\mathrm{R}^{2}=26 \%$; ROC $=0.83$ ) and having a family trust as a power base (pseudo $\mathrm{R}^{2}=39 \%$; ROC $=0.93$ ) appear to be driven by variables of fate. The statistics also misleadingly suggest that obtaining the highest honour (grand-croix) is dependent on variables of fate (pseudo $\mathrm{R}^{2}=37 \%$; ROC $=0.91$ ). However, receiving the highest state honour more likely depends upon entering the FoP than vice versa, and provides an example of endogeneity bias; thus award of the honour is discounted as an explanatory variable. The truly endogenous relationships identified are captured in the structural equation model (SEM) developed below.

[TABLE 4 HERE] 


\section{Structural equation model: the static model}

We adopt an SEM to capture the endogenous nature of variables of choice and the interrelation between different pathways, and define the probability of entering the FoP as one minus the probability of not entering, which facilitates the model. Equation 1 demonstrates that the probability of entering the FoP depends on the probability of not fulfilling any of the four criteria, or of fulfilling just one criterion.
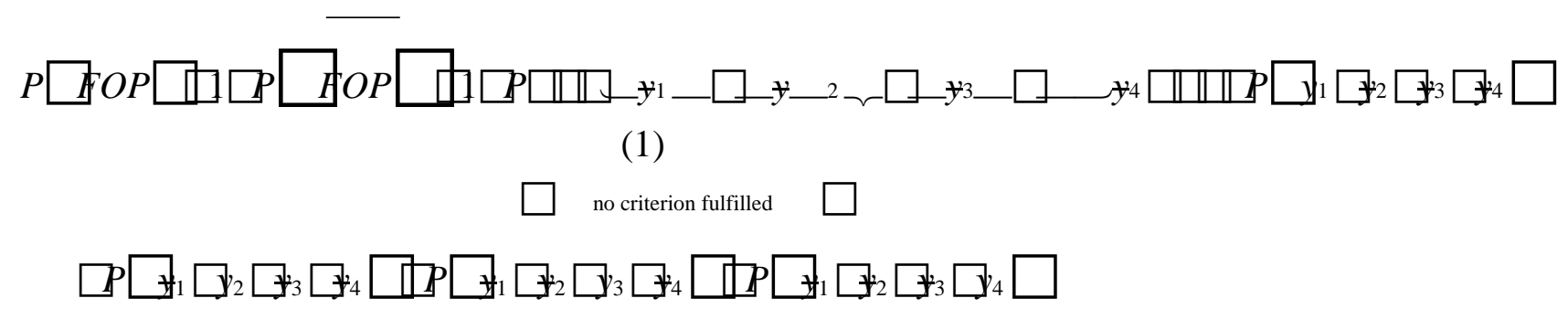

As the individual pathways are interrelated - for example, qualifying as a top-tier director might influence the probability of satisfying other criteria - we need to model the conditional probabilities of the four pathways. We apply an SEM with six equations that reflects the four pathways labelled $y_{j}(\mathrm{j}=1,2,3,4)$ and the two endogenous variables of choice, attending an elite school (eliteschl) and having a family trust as power base ( $\left.p b \_f t\right)$. The four pathways depend on variables of choice $(\mathbf{x})$ and variables of fate (z). The two endogenous variables, eliteschl and $p b \_f t(\mathbf{v})$ can affect the pathways followed, but also depend on variables of fate. Therefore, variables of fate can have a direct effect and an indirect effect through endogenous variables of choice. We use a full-information Maximum-Likelihood (FIML) estimation, which assumes a logistic distribution as the four pathways and the two endogenous variables are binary. The FIML model is estimated in one step, and has the advantage over the standard two-stage procedure in preventing error terms being carried over from the first step. Equation

2 specifies the SEM, the index i referring to individual agents: 


$$
\begin{gathered}
\log \left(\frac{\operatorname{pr}\left(y_{i j}=1 \mid y_{i k \neq j}, \mathbf{x}, \mathbf{z}\right)}{1-\operatorname{pr}\left(y_{i j}=1 \mid y_{i k \neq j}, \mathbf{x}, \mathbf{z}\right)}\right)=\alpha_{j}+\boldsymbol{\beta}^{\prime} \mathbf{x}_{\mathbf{i}}+\mathbf{\gamma}^{\prime} \mathbf{z}_{\mathbf{i}}+\boldsymbol{\rho}^{\prime} \mathbf{v}_{\mathbf{i}}+\sum_{k \neq j} \theta_{k} y_{i k}+\varepsilon_{i j} \\
\log \left(\frac{\operatorname{pr}\left(v_{i l}=1 \mid \mathbf{z}\right)}{1-\operatorname{pr}\left(v_{i l}=1 \mid \mathbf{z}\right)}\right)=\mu_{l}+\Gamma^{\prime} \mathbf{z}_{\mathbf{i}}+\eta_{i l}
\end{gathered}
$$

The results of the SEM, displayed in Table 5 together with various goodness-of-fit measures, are revealing. First, there is confirmation that the four pathways to power are interrelated. As might be expected, becoming CEO of a top 100 French company $\left(y_{1}\right)$ is more likely if agents satisfy other criteria such as involvement in corporate and extra-corporate networks. However, being a networker outside the business sphere $\left(y_{3}\right)$ is not driven by board memberships in the private sector or vice versa $\left(y_{2}\right)$.

Secondly, we can identify a variety of direct effects of explanatory variables on each of the pathways. Elite schooling has a significant positive impact on becoming a corporate networker, but does not influence the likelihood of pursuing any other pathway. Graduating from an elite HE institution, like a grande école, facilitates becoming a CEO, but does not determine other pathways. The type of qualification obtained and subject studied were not found to impact significantly on any of the four pathways. Membership of a grand corps, whose continuing importance is underscored by Dudouet and Joly (2010), has a highly significant positive impact on becoming a networker outside the business sphere $\left(y_{3}\right)$. Individuals coming from backgrounds in public administration and the professions and those with a career platform or power base in finance are advantaged in becoming corporate networkers $\left(y_{2}\right)$. The direct effect of social class is striking in the case of extra-corporate networkers $\left(y_{3}\right)$. Gender does not have a direct influence on pathway choices, although the SEM detects an indirect effect, since women are less likely to attend elite schools, restricting their chances of becoming a corporate networker $\left(y_{2}\right)$ and entering the FoP (Comet \& Finez, 2010). 
Thirdly, we observe highly significant indirect effects of the two variables of fate identified earlier, elite schooling and having a power base in a family trust. Bourdieu (1996) considers the grandes écoles and the FoP to be homologous, the structure of the field of established schools reflecting that of the FoP itself. Being upper or upper-middle class sizeably increases the likelihood of attending one of France's top four grandes écoles, namely ENA, Polytechnique, the Institut des Sciences-Politiques de Paris ('Sciences-Po'), and the Ecole des Hautes Etudes Commerciales (HEC) (Denord et al., 2011; Hartmann, 2000). As many as 28 individuals from class 1 attended Polytechnique, equivalent to $12.9 \%$ of all agents from this social group. Class 2 agents fared much better, 32\% studying there. Our findings suggest that the upper-middle classes dominate the grandes écoles (Comet \& Finez, 2010; Suleiman, 1997). Individuals from the lower classes fared noticeably worse, with just two admitted to Polytechnique, six to ENA, one to Sciences-Po, and none to HEC. Having a family trust as a power base is likewise driven by social class, and by default heightens the probability that the individual concerned is an entrepreneur $\left(y_{4}\right)$.

\section{[TABLE 5 HERE]}

\section{Explaining career trajectories: the dynamic model}

The SEM results are valuable, but they tell us little about career dynamics within the elite and the FoP. In order to understand better the drivers of career transitions and trajectories a dynamic model is required that utilizes the full potential of our dataset. At the outset we observe that many agents (483) maintained pathways between 1998 and 2004, but many others changed pathways (396), and 281 individuals exited due to death or retirement. Based on these trajectories, we can determine a matrix that captures the transition probabilities between pathways. Given four pathways, we model 16 transitions using a generalized linear model (GLM) based on the matrix regression model outlined by Robertson (1990). ${ }^{3}$ There is an evident need to reduce the number of explanatory variables, otherwise there would be a 
risk of over-identification from having 16 equations and 51 explanatory variables (Table 5), which would mean 816 coefficients and greatly reduced degrees of freedom. Hence we draw upon the SEM model to identify a subset of variables with most explanatory power: education (elieschl, elitehe), social class (class_1, class_2, class_3, class_4), gender ( $\left.h \_g e n d e r\right)$, age (age98) and birthplace ( $\left.h \_a f i l, h \_r e g i o n\right)$. To illustrate the model, a transition matrix for the average agent which identifies the variables affecting transition probabilities is plotted in Figure 2. ${ }^{4}$

\section{[FIGURE 2 HERE]}

The arrows in Figure 2 indicate transitions between pathways, while the associated numbers denote transition probabilities expressed as percentages. The related symbols highlight significant coefficients at the 99\% confidence level; plus and minus signs representing positive and negative impacts respectively. The four social classes are labeled C1, C2, C3 and C4; initial pathways are designated Y1, Y2, Y3 and Y4; A refers to age98, F to h_afil and G to h_gender. It is confirmed that agents were largely able to maintain their positions during the seven-year period. For example, $62 \%$ of top tier executives $\left(y_{1}\right)$ remained in position, while $8 \%$ became corporate networkers $\left(y_{2}\right)$ and $14 \%$ became extra-corporate networkers $\left(y_{3}\right)$. The dynamic model also indicates the factors influencing each transition. For instance, the transition from top-tier executive $\left(y_{1}\right)$ to corporate networker $\left(y_{2}\right)$ is positively affected by being a corporate networker and an extra-corporate networker $\left(y_{3}\right)$ in 1998 (symbol Y2(+), Y3(+)). Hence, the CEO of a top 100 company $\left(y_{1}\right)$ who was also director of other top 100 companies $\left(y_{2}\right)$ and organizations outside the business sphere $\left(y_{3}\right)$ was more likely to remain a corporate networker after leaving an executive position.

An important finding is that the third pathway plays a vital role in influencing transition probabilities: having networks outside the business sphere helps an agent remain a corporate networker $\left(y_{2}\right)$. The third pathway also affects the transition between the first and 
second pathways, confirming our premise that pathways are interdependent. Critically, we can observe the direction of influence and confirm the pivotal importance of establishing networks beyond the business world. The dynamic model supports Hypothesis 1: external networks outside the corporate domain influence the likelihood of a transition into other pathways, bolstering power. The model confirms that career trajectories are partly determined by following other pathways, underlining the importance of hyper-agency as stated in Hypothesis 2: following multiple pathways simultaneously consolidates power.

The model reveals that social class counts most when pursuing pathway three, since agents from class 4 are less likely to remain on the third pathway (symbol C4(-)), and accessing it from the first two pathways depends on social class. Therefore, class has an effect on pathways one and two through the ability to form networks beyond the business domain. This supports Hypothesis 3, with social class emerging as the 'master variable' for pathway three, thereby exercising an influence on pathways one and two. Moreover, gender and nationality, being male and French, likewise facilitates joining the third pathway (Martinache, 2011). Ownership, however, does not affect any transition probability and plays a relatively minor role in determining career trajectories.

\section{Hypotheses and empirical findings}

Confirming Hypothesis 1: the role of networks outside the business sphere The FoP cannot be observed directly; however, by using observable pathways, our model can test theoretical predictions. The literature stresses the importance of networks beyond corporate boundaries (Collins-Dogrul, 2012; Geletkanycz \& Hambrick, 1997; Scott, 1991), as represented by pathway three. The static and dynamic models reveal that the third pathway makes retaining a position as corporate networker more likely, enhancing staying power. It also increases an individual's chances of moving from the position of corporate networker to 
a top executive role. This emphasizes the pivotal role of external networks in maintaining power.

Confirming Hypothesis 2: the benefit of hyper-agency

The static and dynamic models reveal that individuals who follow several pathways concurrently increase their likelihood of retaining their position. This underlines the strategic benefit of hyper-agency, which shores up the individual's main role and thereby fosters longevity in the FoP.

\section{Confirming Hypothesis 3: the importance of social class}

Both the static and dynamic models highlight the importance of class origin, through its impact on variables of choice and the capacity to participate in corporate and extra-corporate networks, in becoming and remaining a multi-positional actor within the FoP. Figure 3 is illustrative. It confirms the advantages enjoyed by those from the upper echelons (classes 1 and 2) with respect to all pathways, and highlights the specific advantage enjoyed in extracorporate networking $\left(y_{3}\right)$ by higher-status agents vis-à-vis lower-class aspirants. The general pattern for class 1 is repeated for classes 2 and 3, although the proportions following individual pathways systematically decrease on descending the social scale. Class 4, however, exhibits a different pattern, suggesting that lower-class agents with low stocks of capital on commencing their journey concentrate their careers in the corporate sector, remaining dedicated executives within the confines of their businesses, but often failing to reach the summit, achieving next-best positions. This implies that meritocracy is working in

France. For those who can secure entry to an elite establishment, 'educational socialization' helps compensate for the absence of a high-status background, familiarizing them with its norms and networks (Reay, Crozier \& Clayton, 2009, p. 1105; Palmer \& Barber, 2001). However, there is a caveat: while it may oil the wheels, it is unlikely to secure entry to the FoP (Comet \& Finez, 2010), for reasons we explore below. Conversely, for agents whose 
activities extend beyond corporate boundaries, cementing their position within the FoP as extra-corporate networkers, a high-status background emerges as the 'trump card' (Bourdieu, 1993).

\section{[FIGURE 3 HERE]}

\section{Discussion and Conclusion}

The approach of organization theorists to social class over recent decades has been characterized by a 'silence of critique' (Boltanski \& Chiapello, 2007, p. xiii). We believe this to be mistaken because class, far from being a spent force in determining life chances, continues to exert a material influence on career itineraries and outcomes. However, the extent to which inherited capital continues to determine who occupies the top strata is misrecognized. This matters, because the occupants of command posts hold positions of power over capital, holding sway in contemporary society in setting agendas and capturing resources; the exercise of corporate power going hand-in-hand with the exercise of economic power (Bourdieu, 2011). For lower-class aspirants, class operates as a constraining force, inducing a 'capping effect', such that they often achieve second-tier positions, failing to emerge as hyper-agents (Bourdieu, 1996; Hartmann, 2000) and prevented from accessing ““forbidden” spaces of power’ (Courpasson, Dany \& Clegg, 2012, p. 811). That this remains largely unnoticed is partly because it is concealed by the success of talented challengers in almost making it to the very top, in turn implying their 'doxic acceptance' (Bourdieu, 1987, p. 16) of the given social order, as products of the system of domination they are (mistakenly) presumed to subvert (Courpasson et al., 2012; Fleming \& Spicer, 2007). Social class forces are implicated in invisible but on-going power relationships at this elevated level. The hyperelite layer of the corporate elite is not stand-alone but rests on and is buttressed by those who almost make it to the top. Scrutiny of the impact of social class in regulating entry into 
the FoP is all the more necessary because such spaces of power remain inaccessible to the vast majority of people (Pinçon \& Pinçon-Charlot, 2007).

Our results yield useful insights into the social processes at work. We find, for example, that dominant agents from the most elevated social class do not always extend their reach furthest. Individuals from the upper-middle class often do best, dominating the grandes écoles. It is here that the competing society-wide logics of birth and meritocracy are seamlessly blended, becoming complementary (Thornton, 2002; Thornton \& Ocasio, 1999), and exercising an additive or cumulative effect on life chances, combining direct and indirect effects. Agents from class two are the 'chief beneficiaries of... the reproduction of social and cultural dominance’ (Bennett et al., 2009, p. 177). In succeeding educationally without being excessively prominent in the social hierarchy, displaying the dispositions of class-based advantage without overtly owing their advancement to their background but to their intelligence, they reap a singular profit of legitimacy (Bourdieu \& Saint-Martin, 1973; Suchman, 1995). As Savage et al. (2005, p. 38) bluntly put it, despite omnipresent contestation, the 'advantaged middle classes always win'.

An elite education is especially valuable when a high-status background is lacking. However, we found no guarantee that attending an elite establishment represents a glide-path to the FoP; attendance at a grande école is not the ultimate discriminator it is assumed to be, since many people attend them. This implies that educational socialization alone, without the boost of social class, is unlikely to lead to hyper-agency. Education, while compensatory for lower-class aspirants, does not compensate entirely. The espoused societal logic of meritocracy is not the prevailing logic (Argyris, 1977; Thornton, 2002) when 'the important thing is to know without ever having learnt' (Hartmann, 2000, p. 243); the alternative to this being a protracted, uncertain process of initiation and co-option (Bourdieu, 1990, p. 68).

Social class matters most with respect to pathway three, extra-corporate networking. 
Here, the 'aristocratism of birth' trounces ‘the meritocratism of academic success' (Bourdieu, 1996, p. 335). Education for higher-status agents is justificatory, as the 'advantaged seek to establish... that their unequal positions are deserved’ (Bottero, 2004, p. 996). Inheritance must be seen to be merited to be deemed legitimate (Pinçon \& Pinçon-Charlot, 2007). An extra-corporate networker who is a member of a grand corps increases his or her chances of entering the FoP by an additional 3\%. If s/he is also of high social status, the chances of accessing the FoP rise by a further $4 \%$. The lubricant of high status eases the entry of extracorporate networkers into the FoP, and cements their position within it. This is important, because it is pathway three that leads most directly to the clubs, boardrooms and meeting places which form the 'playing-fields' of the FoP, through which agents engage with other facets, facilitating hyper-agency (Bourdieu, 2011; Giddens, 1984). The preponderance of 'old-timers' in this pathway is indicative of a social class effect that functions to prolong occupancy and bolster agency in the FoP.

An important question is why should this be so? Why does extra-corporate networking exhibit such a striking social class effect? Reference-group dynamics play a critical role here (Bottero, 2004). Such agents benefit from the reassuring mutual resemblance or in-group bias which renders them attractive to their peers, fostering mutual recognition (Ekman, 2012). Put simply, agents from the uppermost classes recognize one another and seek each other out. For Bourdieu (1996, p. 317), mutual recognition is the guiding principle of upper-class groups, since:

'by recognizing themselves in these plenipotentiaries, by recognizing them as endowed with full power to speak and act in their name, [such agents] recognize themselves as members of the class, and in doing so, confer upon it the only form of existence a group can possess'. (Bourdieu, 1987, p. 10)

In other words, high-status agents choose one another, and are chosen in return, forming a corporate class in their own right. This point is confirmed by Mills (1956, pp. 1389): 'Time and time again, in close-ups of the executive career, we observe how men in the 
same circles choose one another'. For Mills (1956, p. 141), joining and engaging in the FoP is not a matter of competence, but one of 'conformity with the criteria of those who have already succeeded. To be compatible with the top men is to act like them, to look like them, to think like them'. The playing-fields of the FoP are not level or neutral. In selecting fellow board members, agents enlist colleagues they can trust, whose behaviour is indicative of value similarity, and with whom they can form lasting alliances (Stern \& Westphal, 2010; Westphal \& Zajac, 1995). Collaborators who exhibit a shared worldview are perceived as more likely to adopt similar strategic positions (Howe, 1978). Stern and Westphal (2010) note that outside directors of high-status origins are more likely to partake in subtle forms of opinion conformity, leading to the garnering of extra-corporate board appointments. Such high-status agents are predisposed to function as ‘agents of connection’ (Bourdieu, 1996, p. 305), unlike lower-status agents who, benefitting less from similarity-attraction bias, are less likely to be chosen, remaining within the corporate domain and keeping 'their (relative) distance' (Bourdieu, 1987, p. 5). This 'structure of affinity or aversion' serves to draw them together (or not) as extra-corporate networkers and fellow-travellers in the FoP (Bourdieu, 1987, p. 7). Interestingly, Bourdieu's discussion of affinity or aversion in the FoP recalls the notion of ‘elective affinities’ proposed by Weber (1948/1971, p. 284), on whose work Bourdieu drew to inform his analysis of power and its impact on life chances (Clegg, 1989; Clegg, Boreham \& Dow, 1986; Clegg et al., 2006). According to this, human relationships mirror processes of attraction and repulsion which govern the aggregation and disaggregation of chemical elements, exhibiting differing inclinations to merge with each other (Howe, 1978; Jost, Frederico \& Napier, 2009; Löwy, 2004). With respect to accumulating extracorporate board appointments, such affinities work, perhaps subliminally, to advantage some 
'through an elective aggregation of those of equal privilege' while subtly disadvantaging others (Bourdieu, 1987, p. 15). This notion of an elective affinity provides a useful metaphor to help elucidate the processes of class-based mutual attraction that bring together high-status agents in durable extra-corporate alliances within the FoP, while simultaneously excluding others (Westphal \& Zajac, 1995), highlighting the potency and natural pulling power of the recognition of a shared class habitus in such circles (Bourdieu, 1990; Hartmann, 2000).

Our findings confirm the three hypotheses advanced concerning extra-corporate networks, hyper-agency and social class; laying the foundations for our unifying theoretical exposition of the enduring importance of the social class effect on the FoP. The main limitation of our study is that its empirical findings pertain to just one nation, and it might reasonably be asked how typical this is. Boltanski and Chiapello (2007), however, argue for limiting analysis to one nation over a defined time-span for findings to be meaningful. Moreover, the conceptual framework we present to inform study of the FoP could be applied to other countries. Comparison with other governance regimes might further illuminate the cultural specificities of the French business system (Genieys, 2005). A second potential limitation is more technical and relates to our treatment of time. Including a panel data analysis might perhaps have better captured agents' entry to and exit from the FoP. However, most explanatory variables such as education and social class do not change with time. We elected instead to explore career trajectories and transitions by means of our dynamic model, which yields insightful results.

Our contribution to the study of corporate elites and their exercise of power at the pinnacle of society is threefold. First, we add to research which conceptualizes processes of hierarchy and internal differentiation within social strata by elaborating and implementing Bourdieu's concept of the FoP. Critical here is the distinction we draw between a majority of corporate leaders whose careers focus on the business domain and a minority who assume a 
role as society-wide playmakers (Denord et al., 2011; François, 2010; Reed, 2012). The methodology we apply to identify dominant agents active within the FoP is innovative, requiring an extensive custom-designed dataset to discern the pathway combinations followed by those who acquire this elevated positioning. The static and dynamic econometric models we develop, unlike those applied in prior elite studies (e.g. Useem \& Karabel, 1986), recognize the inherent endogeneity of socio-economic variables and career pathways, emphasizing the interdependence between pathways and capturing the multidirectional causality between trajectories. This approach allows us to identify the direct and indirect effects of key explanatory variables and to explain the transition probabilities between pathways, highlighting the critical importance of pathway three pursued by extra-corporate networkers in determining hyper-agency. Most importantly, we demonstrate the on-going significance of the social class effect in the selection of hyper-agents who hold sway within the FoP in France.

Our second contribution, building on the first, goes to the heart of corporate elite selection theory. We demonstrate that the subtle, sophisticated preferences which operate unseen to influence selection processes and hence preserve the composition of the French corporate elite are ultimately class-based. While other scholars have highlighted the effect of ingratiating behaviour (Stern \& Westphal, 2010) and demographic similarity such as age (Westphal \& Zajac, 1995) on securing board appointments, our insights accentuate the nature of higher social status as a magnetizing force, with drawing power, instrumental in anchoring position and prolonging activity in the FoP. In contrast to the widespread assumption that class differences have withered away (Bourdieu, 1987), we show that social origin remains a key driver in furthering careers - including at this level where the obviousness of success obscures visible signs of a continuing principle of differentiation (Flemmen, 2012; Palmer \& Barber, 2001) - markedly improving the chances of selection to the corporate and 
extracorporate networks which facilitate hyper-agency. Power contains a demand for recognition (Bourdieu, 2011). Through social interaction dynamics of mutual recognition, which advantage higher-status agents to the detriment of lower-class aspirants, whereby agents become classifiers and are classified in return (Bourdieu, 1987), we show that social class plays a persistent role in the selection mechanisms which determine who holds sway in the corporate elite and, ultimately, society-at-large.

Our third and final contribution is to help re-connect class analysis with organizational analysis, from which it has become disengaged (Clegg, 1989). We propose that research on social class broadly speaking should be re-integrated with the study of organizations and their role in shaping and structuring oligarchical fields of power. Our paper highlights the new texture of social class. The disappearance of class from organizational theory is partly due to the absence of more nuanced class categories grounded in contemporary social and organizational realities (Savage et al., 2013). Bourdieu (1986; 1998) emphasizes the need to construct classes according to meaningful divisions within the social world - to identify an objective class in terms of a set of agents who share homogeneous conditions of existence and common properties, in the form of possessions and power, often legally guaranteed. The common objectified properties shared by top directors in the corporate field create an organizational social class or a corporate-based social class, engendering an '[haute] bourgeoisie of work' (Le Wita, 1994, p. 18). Hyper-agents inhabit a practical world of boards, networks, committees and colloquia which comprise the ‘structuring structures’ for the power elite of corporate capitalism (Bourdieu, 1990, p. 53; Giddens, 1984). This corporate class is organically unified by virtue of an 'incomparable plurality of principles of domination (power or type of capital), which limits competition between power holders and promotes partial and multiple alliances amongst them' (Bourdieu, 2011, p. 137), uniting rivalrous interests in a common ideology. 
Bourdieu's approach to class is a composite one encompassing the institutional foundations of capital formation. Particular forms of capital are endowed with causal power; while inequalities, like types of capital, are not static but accrue over time through processes which implicate institutional systems and individual agency (Savage et al., 2005). The institutions of consecration play a vital role in funnelling or filtering opportunities for access, legitimizing forms of power by according (or withholding) recognition. The organic solidarity of this class engages elite agents and institutions in legitimizing circuits of exchange which are increasingly extensive and complex (Bourdieu, 2011). Bourdieu's (1998) world is not only relational; it is also material. Oligarchic reproduction is accomplished by agents in conjunction with specific rules, frameworks and objects which are teleologically charged, legitimizing differences that are socially relevant (Bourdieu, 1990; Orlikowski, 2007). The objectification of the principles of domination occurs indirectly through the 'intermediary of mechanisms', being 'mediated by things' (Bourdieu, 2011, p. 137). The effect of this process of objectification of class-based differences in qualifications, memberships, symbolic and material goods is to conceal the arbitrary nature of their power while institutionalizing the principles which inform stratification (Le Wita, 1994) - such that a particular career path may appear objectively destined, unsettling the divide between logics of choice and fate through the assumption of an 'objective destiny... imposed by practical reference to the modal trajectory in the class of origin' (Bourdieu, 1986, p. 110). This conjoint work of agents, rules and the objectified properties which legitimize their activities in the organizational field and beyond is what brings class and organizations closer.

Reconnecting class and organizations illuminates our understanding of the mechanisms which sustain corporate power in France today, including the influence of class on social action. The more class-specific interests of the upper echelons are not articulated as explicit goals but remain largely concealed, woven into a rhetoric of shared values and 
common purpose of the French national interest. That the uppermost tier of the corporate elite is drawn primarily from higher-status groups is a matter of theoretical substance and practical relevance, for what is at stake is the right to have voice in policy-making and resource allocation (Hartmann, 2002). A research agenda that combines class and organization theory might shed fresh light on unrecognized mechanisms of power inequalities across generations as well as social strata. To misrecognize the ways in which social class continues to inform processes of hierarchical reproduction is to condone the enduring principles of differentiation and accentuation of class-based inequities in society today.

\section{Funding}

This research received no specific grant from any funding agency in the public, commercial or not-for-profit sectors.

\section{Acknowledgements}

The authors gratefully acknowledge the insightful comments of John Sillince and members of the SOS Research Group based at the Newcastle University Business School, which helped to improve this paper. We also wish to express our gratitude to the Editor-in-Chief David Courpasson and three anonymous Organization Studies reviewers for their thoughtful and perceptive comments which helped us to strengthen our ideas further.

\section{Notes}

1. All translations are by the authors.

2. The period was one of increasing European integration, epitomized by the adoption of the euro in 1999; increasing foreign ownership of the equity of leading French companies; continuing corporate governance initiatives; and the implementation of the Nouvelles Régulations Economiques leading to the loi de sécurité financière of 2003, recommending that the role of PDG become two separate roles, CEO and Chairman. The end of the millennium witnessed a spate of mega-mergers, including hostile takeovers by French firms of fellow rivals, creating TotalFina-Elf and 
BNPParibas; and several Franco-German mergers, producing EADS and Aventis. One might expect to see such far-reaching change reflected in the composition of the body of dominant agents active within the FoP (Dudouet \& Grémont, 2007; François, 2010).

3. An ordered logit approach would suggest a natural order of the 16 transitions, which is not the case.

4. Detailed estimation results can be provided by the authors upon request

\section{References}

Anheier, H.K., Gerhards, J., \& Romo, F.P. (1995). Forms of capital and social structure in cultural fields: Examining Bourdieu's topography. American Journal of Sociology, 100, 859903.

Argyris, C. (1977). Leadership, learning, and changing the status quo. Organizational Dynamics, 76, 29-43.

Ball, S.J. (2008). New philanthropy, new networks and new governance in education. Political Studies, 56, 747-765.

Bauer, M., \& Bertin-Mourot, B. (1997). Radiographie des grands patrons français. Paris: L'Harmattan.

Beck, U. (2008). 'Reframing power in the globalized world'. Organization Studies, 29, 793804.

Bennett, T., Savage, M., Silva, E., Warde, A., Gayo-Cil, M., \& Wright, D. (2009). Culture, class, distinction. London: Routledge.

Boltanski, L. (1973). L'espace positionnel: Multiplicité des positions institutionnelles et habitus de classe. Revue française de sociologie, 14, 3-26.

Boltanski, L. (1982). Les cadres: La formation d’un groupe social. Paris: Minuit.

Boltanski, L., \& Chiapello, E. (2007). The new spirit of capitalism. London: Verso.

Bond, M. (2012). The bases of elite social behaviour: Patterns of affiliation among members of the House of Lords. Sociology, 46, 613-632.

Bottero, W. (2004). Class identities and the identity of class. Sociology, 38, 985-1003.

Bottomore, T.B. (1966). Elites and society. Harmondsworth: Penguin.

Bourdieu, P. (1985). The social space and the genesis of groups. Theory and Society, 14, 723744. 
Bourdieu, P. (1986). Distinction: A social critique of the judgement of taste. London: Routledge.

Bourdieu, P. (1987). What makes a social class? On the theoretical and practical existence of groups. Berkeley Journal of Sociology, 32, 1-17.

Bourdieu, P. (1990). The logic of practice. Cambridge: Polity.

Bourdieu, P. (1993). The field of cultural production. Cambridge: Polity.

Bourdieu, P. (1996). The state nobility: Elite schools in the field of power. Cambridge: Polity.

Bourdieu, P. (1998). Practical reason. Stanford : Stanford University Press.

Bourdieu, P. (2011). Champ du pouvoir et division du travail de domination. Actes de la Recherche en sciences sociales, 190, 126-193.

Bourdieu, P., \& Saint-Martin, M. (1973). Le patronat. Actes de la Recherche en sciences sociales, 20-21, 3-82.

Brown, A.D. (1994). Politics, symbolic action and myth making in pursuit of legitimacy. Organization Studies, 15, 861-878.

Burt, R.S., Hogarth, R.M., \& Michaud, C. (2000). The social capital of French and American managers. Organization Science, 11, 123-147.

Cappelli, P., \& Hamori, M. (2005). The new road to the top. Harvard Business Review, January, 25-32.

Charle, C. (1987). Les élites de la République 1880-1900. Paris: Fayard.

Clegg, S.R. (Ed.) (1989). Organization theory and class analysis: New approaches and new issues. De Gruyter: Berlin.

Clegg, S.R., Boreham, P., \& Dow, G. (1986). Class, politics and the economy. London: Routledge.

Clegg, S.R., Courpasson, D. \& Philips, N. (2006). Power and organizations. London: Sage.

Coignard, S., \& Guichard, M-T. (2000). French connections. New York: Algora.

Collins-Dogrul, J. (2012). Tertius lungens brokerage and transnational intersectoral cooperation. Organization Studies, 33, 989-1014.

Comet, C., \& Finez, J. (2010). Le coeur de l'élite patronale: Reproduction sociale et réseaux de gouvernance. Sociologies pratiques, 21, 49-66. 
Courpasson, D. (2000). Managerial strategies of domination: Power in soft bureaucracies. Organization Studies, 21, 141-161.

Courpasson, D., Arellano-Gault, D., Brown, A., \& Lounsbury, M. (2008). Organization Studies on the look-out? Being read, being listened to. Organization Studies, 29, 1383-1390.

Courpasson, D., \& Clegg, S.R. (2006). Dissolving the iron cages? Tocqueville, Michels, bureaucracy and the perpetuation of elite power. Organization, 13, 319-343.

Courpasson, D., Dany, F., \& Clegg, S. (2012). Resisters at work: Generating productive resistance in the workplace. Organization Science, 23, 801-819.

Courpasson, D., \& Golsorkhi, D. (2009). Les productivités du pouvoir. Revue française de gestion, 193, 61-71.

Davis, G.F., \& Greve, H.R. (1997). Corporate elite networks and governance changes in the 1980s. American Journal of Sociology, 103, 1-37.

Davis, G.F., Yoo, M., \& Baker, W.E. (2003). The small world of the American corporate elite, 1982-2001. Strategic Organization, 1, 301-326.

Denord, F., Lagneau-Ymonet, P., \& Thine, S. (2011). Le champ du pouvoir en France. Actes de la Recherche en sciences sociales, 190, 24-57.

Dezalay, Y. (1995). 'Turf battles' or 'class struggles': The internationalization of the market for expertise in the 'professional society'. Accounting, Organizations and Society, 20, 331344.

Dudouet, F-X., \& Grémont, E. (2007). Les grands patrons et l’Etat en France 1981-2007. Sociétés contemporaines, 68, 105-131.

Dudouet, F-X., \& Joly, H. (2010). Les dirigeants français du CAC 40: Entre élitisme scolaire et passage par l'Etat. Sociologies pratiques, 21, 35-46.

Ekman, S. (2012). Fantasies about work as limitless potential - how managers and employees seduce each other through dynamics of mutual recognition. Human Relations, 66, 1-23.

Eymeri, J-M. (2001). La fabrique des énarques. Paris: Economica.

Flemmen, M. (2012). The structure of the upper class: A social space approach. Sociology, 46, 1039-1058.

Fleming, P., \& Spicer, A. (2007). Contesting the corporation. Cambridge: CUP.

François, P. (2010). Les guépards du capitalisme français? Structure de l'élite patronale et modes d'accès aux positions dominantes. Paper presented at 'Les élites économiques en France et en Europe', DRM-IRISSO, Paris-Dauphine. 
Franks, J., \& Mayer, C. (1997). Corporate ownership and control in the UK, Germany and France. Journal of Applied Corporate Finance, 9, 30-45.

Geletkanycz, M.A., \& Hambrick, D.C. (1997). The external ties of top executives:

Implications for strategic choice and performance. Administrative Science Quarterly, 42, 654681.

Genieys, W. (2005). The sociology of political elites in France: The end of an exception?. International Political Science Review, 26, 413-430.

Giddens, A. (1984). The constitution of society. Cambridge: Polity.

Godechot, O. (2011). Finance and the rise of inequalities in France. Working Paper 13. Paris School of Economics.

Goethe, J.W. von (1809/1971). Elective affinities. Harmondsworth: Penguin.

Golsorkhi, D., Leca, B., Lounsbury, M., \& Ramirez, C. (2009). Analysing, accounting for and unmasking domination: On our role as scholars of practice, practitioners of social science and public intellectuals. Organization, 16, 779-797.

Granovetter, M. (1974). Getting a job. Cambridge, MA: Harvard University Press.

Grant, R.R. (1997). Measuring corporate power: Assessing the options. Journal of Economic Issues, 31, 453-460.

Greene, W.H. (2008). Econometric analysis, $7^{\text {th }}$ edn. Prentice Hall: New York.

Gunz, H., Mayrhofer, W., \& Tolbert, P. (2011). Career as a social and political phenomenon in the globalized economy. Organization Studies, 32, 1613-1620.

Halsey, A.H. (1995). Change in British society, $4^{\text {th }}$ edn. Oxford: OUP.

Hamdouch, A. (1989). L'Etat d'influence. Paris: CNRS.

Hartmann, M. (2000). Class-specific habitus and the social reproduction of the business elite in Germany and France. Sociological Review, 42, 241-261.

Hartmann, M. (2002). Der Mythos von den Leistungs-eliten: Spitzenkarrieren und soziale Herkunft in Wirtschaft, Politik, Justiz und Wissenschaft. Frankfurt: Campus.

Hartmann, M. (2011). Internationalisation et spécificités nationales des élites économiques. Actes de la Recherche en sciences sociales, 190, 10-23.

Hebson, G. (2009) Renewing class analysis in studies of the workplace: A comparison of working-class and middle-class women's aspirations. Sociology, 43, 27-44. 
Hjellbrekke, J., Roux, B., Korsnes, O., Lebaron, F., Rosenlund, L., \& Rouanet, H. (2007). The Norwegian field of power anno 2000. European Societies, 9, 245-273.

Howe, R.H. (1978). Max Weber's elective affinities: Sociology within the bounds of pure reason. American Journal of Sociology, 84, 366-385.

Iellatchitch, A., Mayrhofer, W., \& Meyer, M. (2003). Career fields: A small step towards a grand career theory? International Journal of Human Resource Management, 14, 728-750.

Jost, J.T., Frederico, C.M., \& Napier, J.L. (2009). Political ideology: Its structure, function, and elective affinities. Annual Review of Psychology, 60, 307-337.

Kadushin, C. (1995). Friendship among the French financial elite. American Sociological Review, 60, 202-221.

Kerr, R., \& Robinson, S. (2012). From symbolic violence to economic violence: The globalizing of the Scottish banking elite. Organization Studies, 33, 247-266.

Le Wita, B. (1994). French bourgeois culture. Cambridge: CUP.

Lévy-Leboyer, M. (1979). Le patronat français, 1912-1973. In Le patronat de la seconde industrialisation. M. Lévy-Leboyer (Ed.), 137-188. Paris: Editions ouvrières.

Lindsay, D.M. (2008). Evangelicals in the power elite: Elite cohesion advancing a movement. American Sociological Review, 73, 60-82.

Lounsbury, M., \& Glynn, M.A. (2001). Cultural entrepreneurship: Stories, legitimacy, and the acquisition of resources. Strategic Management Journal, 22, 545-564.

Löwy, M. (2004). Le concept d'affinité élective chez Max Weber. Archives de Sciences Sociales des Religions, 127, 93-103.

Maclean, M. (2002). Economic Management and French Business from de Gaulle to Chirac. Basingstoke: Palgrave Macmillan.

Maclean, M., Harvey, C., \& Chia, R. (2010). Dominant corporate agents and the power elite in France and Britain. Organization Studies, 31, 327-348.

Maclean, M., Harvey, C., \& Press, J. (2006). Business elites and corporate governance in France and the UK. Basingstoke: Palgrave Macmillan.

Martinache, I. (2011). Le pouvoir économique: Classes sociales et modes de domination. Actes de la Recherche en sciences sociales, 190, 1-5.

McLeod, C., O’Donohoe, S., \& Townley, B. (2009). The elephant in the room? Class and creative careers in British advertising agencies. Human Relations, 62, 1011-1039. 
Mills, C.W. (1956). The power elite. Oxford: OUP.

Oakes, L.S., Townley, B., \& Cooper, D.J. (1998). Business planning as pedagogy: Language and control in a changing institutional field. Administrative Science Quarterly, 43, 257-292.

O’Mahony, S., \& Bechky, B.A. (2008). Boundary organizations: Enabling collaboration among unexpected allies. Administrative Science Quarterly, 53, 422-459.

Orlikowski, W.J. (2007). Sociomaterial practices: Exploring technology at work. Organization Studies, 28, 1435-1448.

Palmer, D., \& Barber, B.M. (2001). Challengers, elites, and owning families: A social class theory of corporate acquisitions in the 1960s. Administrative Science Quarterly, 46, 87-120.

Pinçon, M., \& Pinçon-Charlot, M. (1998). Grandes fortunes. Paris: Payot.

Pinçon, M., \& Pinçon-Charlot, M. (2002). Voyage en grande bourgeoisie. Paris: PUF.

Pinçon, M., \& Pinçon-Charlot, M. (2007). Sociologie de la bourgeoisie. Paris: La Découverte.

Reay, D., Crozier, G., \& Clayton, J. (2009). 'Strangers in paradise’? Working-class students in elite universities. Sociology, 43, 1103-1121.

Reed, M.I. (2012). Masters of the universe: Power and elites in organization studies. Organization Studies, 33, 203-221.

Robertson, C. (1990). A matrix regression model for the transition probabilities in a finite state stochastic process. Journal of the Royal Statistical Society, Series C, 39, 1-19.

Savage, M., Devine, F., Cunningham, N., Taylor, M., Li, Y., Hjellbrekke, J., Le Roux, B., Freidman, S., \& Miles, A. (2013). A new model of social class? Findings from the BBC's great British class survey. Sociology, forthcoming.

Savage, M., Warde, A., \& Devine, F. (2005). Capitals, assets, and resources: some critical issues'. British Journal of Sociology, 56, 31-47.

Savage, M., \& Williams, K. (2008). Elites: Remembered in capitalism and forgotten by social sciences. The Sociological Review, 56, 1-24.

Schervish, P.G. (2003). Hyperagency and high tech donors. Boston, MA: Social Welfare Research Institute.

Scott, J. (1991). Networks of corporate power: A comparative assessment. Annual Review of Sociology, 17, 181-203. 
Scott, J. (2002). Social class and stratification in late modernity. Acta Sociologa, 45, 23-35.

Skeggs, B. (2004). Context and background: Pierre Bourdieu's analysis of class, gender and sexuality. The Sociological Review, 52, 19-33.

Stern, I., \& Westphal, J.D. (2010). Stealthy footsteps to the boardroom: Executives' backgrounds, sophisticated interpersonal influence behaviour, and board appointments. Administrative Science Quarterly, 55, 278-319.

Suleiman, E. (1978). Elites in French society. Princeton: Princeton University Press.

Suleiman, E. (1997). Les élites de l'administration et de la politique. In Le Recrutement des élites en Europe. E. Suleiman and H. Mendras (eds.), Paris: La Découverte.

Swartz, D.L. (2008). 'Bringing Bourdieu’s master concepts into organizational analysis'. Theory and Society, 37, 45-52.

Thornton, P.H. (2002). The rise of the corporation in a craft industry: Conflict and conformity in institutional logics. Academy of Management Journal, 45, 81-101.

Thornton, P.H., \& Ocasio, W. (1999). Institutional logics and the historical contingency of power in organizations. American Journal of Sociology, 105, 801-844.

Useem, M. (1984). The inner circle: Large corporations and the rise of business political activity in the US and UK. Oxford: OUP.

Useem, M., \& Karabel, J. (1986). Pathways to top corporate management. American Sociological Review, 51, 184-200.

Wacquant, L.J.D. (1993). From ruling class to field of power: An interview with Pierre Bourdieu on La noblesse d'état. Theory, Culture and Society, 10, 19-44.

Wagner, A-C. (2011). Les classes dominantes à l'épreuve de la mondialisation. Actes de la Recherche en sciences sociales, 190, 4-9.

Weber, M. (1948/1991). Essays in sociology. London: Routledge.

Westphal, J.D., \& Zajac, E.J. (1995). Who shall govern? CEO/board power, demographic similarity, and new director selection. Administrative Science Quarterly, 40, 60-83.

Yeo, H-J., Pochet, C., \& Alcouffe, A. (2003). CEO reciprocal interlocks in French corporations. Journal of Management and Governance, 7, 87-108.

Zajac, E.J., \& Westphal, J.D. (1996). Director reputation, CEO-board power, and the dynamics of board interlocks. Administrative Science Quarterly, 41, 507-529. 
Zald, M.N., \& Lounsbury, M. (2010). The wizards of Oz: Towards an institutional approach to elites, expertise and command posts. Organization Studies, 31, 963-996.

Table 1: Qualifications and entry into the FoP

Part A: Entry Qualifications (observations $=1160$ )

\begin{tabular}{lclll}
\hline \multicolumn{1}{c}{ Pathway } & No. qualifying & $\begin{array}{l}\% \\
\text { qualifying }\end{array}$ & $\begin{array}{l}\text { No. within } \\
\text { FoP }\end{array}$ & $\begin{array}{l}\text { \% within } \\
\text { FoP }\end{array}$ \\
\hline Top-Tier Executive (y1) & 198 & 17.1 & 180 & 90.9 \\
Corporate Networker (y2) & 366 & 31.6 & 309 & 84.4 \\
Extra-Corporate Networker (y3) & 555 & 47.8 & 379 & 68.3 \\
Ownership (y4) & 52 & 4.5 & 47 & 90.4
\end{tabular}

Part B: Entrants into the Field of Power (386 of 1160)

\begin{tabular}{|c|c|c|c|}
\hline Type of actor in FoP & $\begin{array}{l}\text { Pathway } \\
\text { combination }\end{array}$ & $\begin{array}{l}\text { No. of } \\
\text { entrants into } \\
\text { FoP }\end{array}$ & $\begin{array}{l}\text { \% of entrants } \\
\text { into FoP }\end{array}$ \\
\hline $\begin{array}{l}\text { Corporate \& Extra-Corporate } \\
\text { Networker }\end{array}$ & $\mathrm{y} 2+\mathrm{y} 3$ & 182 & 47.2 \\
\hline $\begin{array}{l}\text { Top-Tier Corporate \& } \\
\text { ExtraCorporate Networker }\end{array}$ & $\mathrm{y} 1+\mathrm{y} 2+\mathrm{y} 3$ & 94 & 24.4 \\
\hline $\begin{array}{l}\text { Top-Tier Extra-Corporate } \\
\text { Networker }\end{array}$ & $\mathrm{y} 1+\mathrm{y} 3$ & 58 & 15.0 \\
\hline $\begin{array}{l}\text { Top-Tier Owner Corporate \& } \\
\text { Extra-Corporate Networker }\end{array}$ & $\mathrm{y} 1+\mathrm{y} 2+\mathrm{y} 3+\mathrm{y} 4$ & 15 & 3.9 \\
\hline $\begin{array}{l}\text { Owner Corporate \& } \\
\text { ExtraCorporate Networker }\end{array}$ & $\mathrm{y} 2+\mathrm{y} 3+\mathrm{y} 4$ & 12 & 3.1 \\
\hline Owner Extra-Corporate Networker & $\mathrm{y} 3+\mathrm{y} 4$ & 12 & 3.1 \\
\hline $\begin{array}{l}\text { Top-Tier Owner Extra-Corporate } \\
\text { Networker }\end{array}$ & $\mathrm{y} 1+\mathrm{y} 3+\mathrm{y} 4$ & 6 & 1.6 \\
\hline Top-Tier Corporate Networker & $\mathrm{y} 1+\mathrm{y} 2$ & 5 & 1.3 \\
\hline $\begin{array}{l}\text { Top-Tier Owner Corporate } \\
\text { Networker }\end{array}$ & $\mathrm{y} 1+\mathrm{y} 2+\mathrm{y} 4$ & 1 & 0.3 \\
\hline Top-Tier Owner & $\mathrm{y} 1+\mathrm{y} 4$ & 1 & 0.3 \\
\hline
\end{tabular}

Table 2: Descriptive statistics (observations, mean, standard deviation)

\begin{tabular}{llllllll}
\hline Variable & Obs & Mean & Std & Variable & Obs & Mean & Std \\
\hline y1 & 1160 & 0.17 & 0.38 & FIN & 1160 & 0.22 & 0.41 \\
y2 & 1160 & 0.32 & 0.46 & GMT & 1160 & 0.24 & 0.43
\end{tabular}




\begin{tabular}{llllllll} 
y3 & 1160 & 0.48 & 0.50 & HRM & 1160 & 0.02 & 0.15 \\
y4 & 1160 & 0.04 & 0.21 & LAW & 1160 & 0.03 & 0.17 \\
eliteschl & 923 & 0.56 & 0.50 & M_M & 1160 & 0.07 & 0.25 \\
elitehe & 1112 & 0.78 & 0.41 & OWN & 1160 & 0.02 & 0.15 \\
dis_ahss & 1119 & 0.04 & 0.20 & PAD & 1160 & 0.08 & 0.27 \\
dis_bea & 1119 & 0.42 & 0.49 & tyear & 1160 & 1988.5 & 9.50 \\
dis_lop & 1119 & 0.12 & 0.32 & tage & 1160 & 45.79 & 8.19 \\
dis_sem & 1119 & 0.37 & 0.48 & t98 & 1160 & 1.24 & 0.77 \\
qual_fd & 1119 & 0.11 & 0.31 & oth98 & 1160 & 0.89 & 1.32 \\
qual_hd & 1119 & 0.73 & 0.44 & t04 & 1160 & 0.71 & 0.84 \\
qual_phd & 1119 & 0.11 & 0.31 & oth04 & 1160 & 0.91 & 1.24 \\
profqual & 1118 & 0.53 & 0.50 & pb_ac & 1160 & 0.01 & 0.11 \\
pqtype_af & 1119 & 0.11 & 0.32 & pb_bf & 1160 & 0.06 & 0.23 \\
pqtype_ag & 1119 & 0.01 & 0.11 & pb_b & 1160 & 0.72 & 0.45 \\
pqtype_bi & 1119 & 0.01 & 0.07 & pb_ft & 1160 & 0.16 & 0.36 \\
pqtype_et & 1119 & 0.27 & 0.45 & pb_l & 1160 & 0.01 & 0.08 \\
pqtype_l & 1119 & 0.06 & 0.23 & pb_s & 1160 & 0.06 & 0.23 \\
pqtype_mba & 1119 & 0.06 & 0.25 & exnet & 1160 & 1.44 & 1.19 \\
chevaliers & 1160 & 0.17 & 0.38 & cbd & 1160 & 0.15 & 0.35 \\
officiers & 1160 & 0.13 & 0.34 & pbody & 1160 & 0.46 & 0.50 \\
commandeurs & 1160 & 0.07 & 0.26 & bassoc & 1160 & 0.51 & 0.50 \\
grand_off & 1160 & 0.01 & 0.11 & edbd & 1160 & 0.22 & 0.41 \\
grand_croix & 1160 & 0.00 & 0.06 & asbd & 1160 & 0.11 & 0.31 \\
corps_1 & 1160 & 0.01 & 0.07 & con_no & 1160 & 3.57 & 2.43 \\
corps_2 & 1160 & 0.05 & 0.23 & con_span & 1160 & 2.86 & 1.41 \\
corps_3 & 1160 & 0.02 & 0.13 & class_1 & 1160 & 0.19 & 0.39 \\
corps_4 & 1160 & 0.05 & 0.22 & class_2 & 1160 & 0.40 & 0.49 \\
corps_5 & 1160 & 0.02 & 0.15 & class_3 & 1160 & 0.30 & 0.46 \\
type_b & 1159 & 0.72 & 0.45 & class_4 & 1160 & 0.05 & 0.22 \\
type_pa_b & 1159 & 0.24 & 0.43 & h_gender & 1160 & 0.96 & 0.21 \\
type_p_b & 1159 & 0.04 & 0.19 & h_region & 1160 & 0.31 & 0.46 \\
ACAD & 1160 & 0.02 & 0.13 & age98 & 1160 & 55.39 & 9.50 \\
EST & 1160 & 0.26 & 0.44 & h_afil & 1159 & 0.90 & 0.30 \\
\hline & & & & & & & \\
\hline
\end{tabular}

Table 3: MANOVA: Test statistics for differences between groups (in versus out of FoP)

\begin{tabular}{llllll}
\hline Variable & $\begin{array}{l}\text { Wilks' } \\
\text { lamda }\end{array}$ & p-value & Variable & $\begin{array}{l}\text { Wilks' } \\
\text { lamda }\end{array}$ & p-value \\
\hline eliteschl & 1.000 & 0.946 & HRM & 1.000 & 0.833 \\
elitehe & 1.000 & 0.588 & LAW & 1.000 & 0.546 \\
dis_ahss & 1.000 & 0.893 & M_M & 1.000 & 0.632 \\
dis_bea & 1.000 & 0.790 & OWN & 0.999 & 0.394 \\
dis_lop & 1.000 & 0.504 & PAD & 0.999 & 0.432 \\
dis_sem & 1.000 & 0.674 & tyear & 1.000 & 0.363 \\
qual_fd & 1.000 & 0.994 & tage & $0.996^{*}$ & 0.063
\end{tabular}




\begin{tabular}{llllll} 
qual_hd & 1.000 & 0.956 & t98 & $0.987^{* * *}$ & 0.001 \\
qual_phd & 1.000 & 0.935 & oth98 & $0.986^{* * *}$ & 0.001 \\
profqual & 0.998 & 0.248 & t04 & $0.990^{* * *}$ & 0.003 \\
pqtype_af & 1.000 & 0.639 & oth04 & 0.998 & 0.238 \\
pqtype_ag & 1.000 & 0.940 & pb_bf & 1.000 & 0.900 \\
pqtype_bi & 0.999 & 0.489 & pb_b & 1.000 & 0.826 \\
pqtype_et & 0.999 & 0.350 & pb_ft & 1.000 & 0.931 \\
pqtype_1 & 0.999 & 0.379 & pb_l & 1.000 & 0.588 \\
pqtype_mba & 0.998 & 0.236 & pb_s & 1.000 & 0.886 \\
chevaliers & $0.996^{*}$ & 0.066 & exnet & $0.990^{* * *}$ & 0.003 \\
officiers & 1.000 & 0.606 & cbd & 0.998 & 0.232 \\
commandeurs & 1.000 & 0.978 & pbody & 1.000 & 0.960 \\
grand_off & $0.993^{* *}$ & 0.012 & bassoc & 1.000 & 0.841 \\
grand_croix & 1.000 & 0.768 & edbd & 1.000 & 0.804 \\
corps_1 & 1.000 & 0.938 & asbd & 0.997 & 0.104 \\
corps_2 & $0.995^{* *}$ & 0.041 & con_no & $0.994^{* *}$ & 0.020 \\
corps_3 & 0.999 & 0.284 & con_span & $0.996 *$ & 0.052 \\
corps_4 & $0.994^{* *}$ & 0.024 & class_1 & 1.000 & 0.634 \\
corps_5 & 1.000 & 0.901 & class_2 & 0.999 & 0.368 \\
type_pa_b & 0.999 & 0.273 & class_3 & 1.000 & 0.670 \\
type_p_b & 0.999 & 0.303 & h_gender & 1.000 & 0.680 \\
EST & 1.000 & 0.521 & h_region & 0.999 & 0.470 \\
FIN & 0.999 & 0.418 & age98 & 0.998 & 0.230 \\
GMT & 1.000 & 0.547 & h_afil & $0.987^{* * * *}$ & 0.001 \\
\hline ALL & $0.364^{* * *}$ & 0.000 & & & \\
\hline
\end{tabular}

${ }^{*} \mathrm{p}<0.10,{ }^{* *} \mathrm{p}<0.05, * * * \mathrm{p}<0.01$

Reference categories: type_b, ACAD, pb_ac, class_4

Table 4: Endogeneity: Auxiliary regressions

\begin{tabular}{llll}
\hline Variable & Rsquared & Variable & Rsquared \\
\hline eliteschl & $0.26 \dagger$ & corps_3 & 0.02 \\
elitehe & 0.18 & corps_4 & 0.13 \\
dis_ahss & 0.09 & corps_5 & 0.00 \\
dis_bea & 0.03 & type_pa_b & 0.17 \\
dis_lop & 0.06 & type_p_b & 0.04 \\
dis_sem & 0.04 & EST & 0.08 \\
qual_fd & 0.13 & FIN & 0.06 \\
qual_hd & 0.11 & GMT & 0.06 \\
qual_phd & 0.04 & HRM & 0.12 \\
profqual & 0.03 & LAW & 0.05 \\
pqtype_af & 0.03 & M_M & 0.06 \\
pqtype_ag & 0.04 & PAD & 0.05 \\
pqtype_bi & 0.17 & pb_bf & 0.11
\end{tabular}




\begin{tabular}{llll} 
pqtype_et & 0.04 & pb_b & 0.06 \\
pqtype_l & 0.06 & pb_ft & $0.39 \dagger$ \\
pqtype_mba & 0.03 & pb_l & 0.09 \\
chevaliers & 0.04 & pb_s & 0.03 \\
officiers & 0.09 & exnet & 0.11 \\
commandeurs & 0.17 & cbd & 0.16 \\
grand_off & 0.08 & pbody & 0.10 \\
grand_croix & $0.37 \dagger$ & bassoc & 0.07 \\
corps_1 & 0.10 & edbd & 0.05 \\
corps_2 & 0.05 & asbd & 0.11 \\
\hline
\end{tabular}

† Adjusted R-squared exceeds threshold of 25\%.

Table 5: Results of the static model (coefficients and significance tests)

\begin{tabular}{|c|c|c|c|c|c|c|}
\hline Variable & y1 & y2 & y3 & $\mathrm{y} 4$ & eliteschl & $\mathrm{pb} \_\mathrm{ft}$ \\
\hline y1 & & $0.11^{*}$ & $0.05^{*}$ & $0.02 *$ & & \\
\hline y2 & $0.08 *$ & & 0.02 & $0.02 *$ & & \\
\hline y3 & $0.10 *$ & 0.04 & & 0.00 & & \\
\hline y4 & $0.20 *$ & $0.29 *$ & 0.00 & & & \\
\hline eliteschl & -0.02 & $0.08^{*}$ & 0.01 & -0.01 & & \\
\hline elitehe & $0.07 *$ & -0.01 & 0.00 & 0.00 & & \\
\hline dis_ahss & 0.07 & 0.07 & 0.03 & $-0.11^{*}$ & & \\
\hline dis_bea & 0.11 & 0.07 & 0.05 & -0.04 & & \\
\hline dis_lop & 0.09 & 0.08 & 0.02 & -0.04 & & \\
\hline dis_sem & 0.14 & 0.04 & 0.00 & -0.05 & & \\
\hline qual_fd & -0.12 & 0.03 & -0.08 & 0.06 & & \\
\hline qual_hd & -0.16 & 0.00 & -0.06 & 0.04 & & \\
\hline qual_phd & -0.15 & 0.02 & -0.10 & 0.02 & & \\
\hline profqual & 0.05 & -0.02 & 0.07 & -0.04 & & \\
\hline pqtype_af & 0.01 & -0.03 & -0.05 & 0.05 & & \\
\hline pqtype_ag & -0.12 & 0.00 & -0.03 & -0.03 & & \\
\hline pqtype_bi & 0.17 & 0.19 & -0.15 & 0.02 & & \\
\hline pqtype_et & -0.08 & 0.02 & -0.06 & 0.05 & & \\
\hline pqtype_l & 0.01 & -0.07 & 0.05 & 0.04 & & \\
\hline pqtype_mba & 0.02 & 0.05 & -0.06 & 0.05 & & \\
\hline chevaliers & 0.02 & 0.03 & -0.01 & -0.01 & & \\
\hline officiers & 0.04 & 0.08 & 0.02 & -0.02 & & \\
\hline commandeur 1 & -0.01 & $0.15^{*}$ & 0.07 & -0.01 & & \\
\hline grand_off & 0.04 & -0.02 & 0.09 & -0.04 & & \\
\hline corps_1 & $-0.31 * * *$ & 0.06 & $0.22 * *$ & 0.02 & & \\
\hline corps_2 & 0.03 & 0.01 & $0.14^{* *}$ & -0.02 & & \\
\hline corps_3 & -0.10 & -0.10 & $0.23 * * *$ & 0.00 & & \\
\hline corps_4 & 0.02 & -0.12 & $0.19 * * *$ & -0.02 & & \\
\hline corps_5 & -0.09 & 0.04 & 0.04 & -0.01 & & \\
\hline type_pa_b & -0.07 & $0.16^{*}$ & $-0.09 *$ & 0.01 & & \\
\hline
\end{tabular}




\begin{tabular}{|c|c|c|c|c|c|c|}
\hline type_p_b & $-0.27 * * *$ & $0.29 *$ & -0.10 & $-0.30 * * *$ & & \\
\hline EST & -0.03 & 0.14 & -0.03 & $-0.73^{* * *}$ & & \\
\hline FIN & -0.10 & $0.31^{* *}$ & -0.06 & $-0.74 * * *$ & & \\
\hline GMT & 0.02 & 0.16 & -0.02 & $-0.74 * * *$ & & \\
\hline HRM & -0.10 & 0.11 & -0.05 & $-0.71 * * *$ & & \\
\hline LAW & 0.02 & 0.20 & -0.13 & $-0.60 * * *$ & & \\
\hline M_M & -0.07 & 0.13 & -0.04 & $-0.72 * * *$ & & \\
\hline PAD & -0.04 & 0.07 & 0.00 & $-0.74 * * *$ & & \\
\hline pb_bf & 0.04 & $0.51^{* *}$ & -0.05 & $0.36 * * *$ & & \\
\hline pb_b & 0.14 & 0.14 & -0.08 & $0.37 * * *$ & & \\
\hline pb_ft & 0.04 & 0.19 & 0.03 & $0.41^{* * *}$ & & \\
\hline pb_l & 0.09 & $-0.41^{*}$ & 0.08 & $0.55^{* * *}$ & & \\
\hline pb_s & -0.03 & 0.15 & -0.05 & $0.37 * * *$ & & \\
\hline cbd & 0.05 & 0.02 & $0.25 * * *$ & 0.02 & & \\
\hline pbody & $0.12^{* *}$ & 0.02 & $0.35^{* * *}$ & 0.01 & & \\
\hline bassoc & $0.09 * *$ & $0.16^{* * *}$ & $0.38 * * *$ & $0.02 *$ & & \\
\hline edbd & 0.08 & $0.11 *$ & $0.30 * * *$ & 0.00 & & \\
\hline asbd & 0.02 & $0.10 *$ & $0.24 * * *$ & 0.00 & & \\
\hline class_1 & -0.03 & -0.11 & $0.18 * * *$ & -0.01 & $0.62 * * *$ & $0.55 * * *$ \\
\hline class_2 & -0.03 & -0.06 & $0.11^{* *}$ & 0.01 & $0.53^{* * *}$ & $0.08 * * *$ \\
\hline class_3 & -0.04 & -0.10 & $0.07 *$ & 0.01 & 0.03 & $0.04 * *$ \\
\hline h_gender & 0.08 & -0.10 & -0.03 & 0.04 & $0.28 * * *$ & -0.07 \\
\hline h_region & -0.04 & 0.03 & 0.02 & -0.01 & $0.15^{* * *}$ & $-0.06 * * *$ \\
\hline age98 & $-0.01 * * *$ & 0.00 & 0.00 & 0.00 & 0.00 & $0.00 * * *$ \\
\hline h_afil & 0.09 & $-0.42 * * *$ & $-0.14^{* *}$ & 0.02 & -0.11 & 0.00 \\
\hline Constant & 0.15 & 0.14 & 0.12 & $0.28 * *$ & 0.01 & -0.16 \\
\hline \multicolumn{7}{|c|}{ Goodness-of-fit measures } \\
\hline df & 880 & & & & & \\
\hline Chi2 & 797.485 & & & & & \\
\hline P-value & 0.979 & & & & & \\
\hline GFI & 0.763 & & & & & \\
\hline AGFI & 0.994 & & & & & \\
\hline RMSEA & 0.000 & & & & & \\
\hline MC & 1.046 & & & & & \\
\hline
\end{tabular}

Note: The goodness-of-fit measures include the Chi-square test statistic $\left(\mathrm{Chi}^{2}\right)$, the associated p-value, the general fit index (GFI), the adjusted general fit index (AGFI), the root mean square error of approximation (RMSEA) and the McDonald's centrality index (MC). The first four columns in Table 5 refer to the direct effects of explanatory variables on the pathways ( $\mathrm{x}$ $\rightarrow \mathrm{y}$ and $\mathrm{z} \rightarrow \mathrm{y})$. Column five and six show the impact of the variables of fate $(\mathrm{z})$ on eliteschl and $p b \_f t(\mathrm{z} \rightarrow \mathrm{x})$. Hence, the indirect effect refers to $(\mathrm{z} \rightarrow \mathrm{x} \rightarrow \mathrm{y})$. Direct and indirect effects are additive, as a chance in a variable of fate $(\mathrm{z})$ affects pathways $(\mathrm{y})$ directly $(\mathrm{z} \rightarrow \mathrm{y})$ and indirectly $(\mathrm{z} \rightarrow \mathrm{x} \rightarrow \mathrm{y})$.

$* \mathrm{p}<0.05, * * \mathrm{p}<0.01, * * * \mathrm{p}<0.001$ 
Figure 1: Conceptual framework

Field of Power (FoP)

To enter the FoP: at least two out of four pathways must be followed

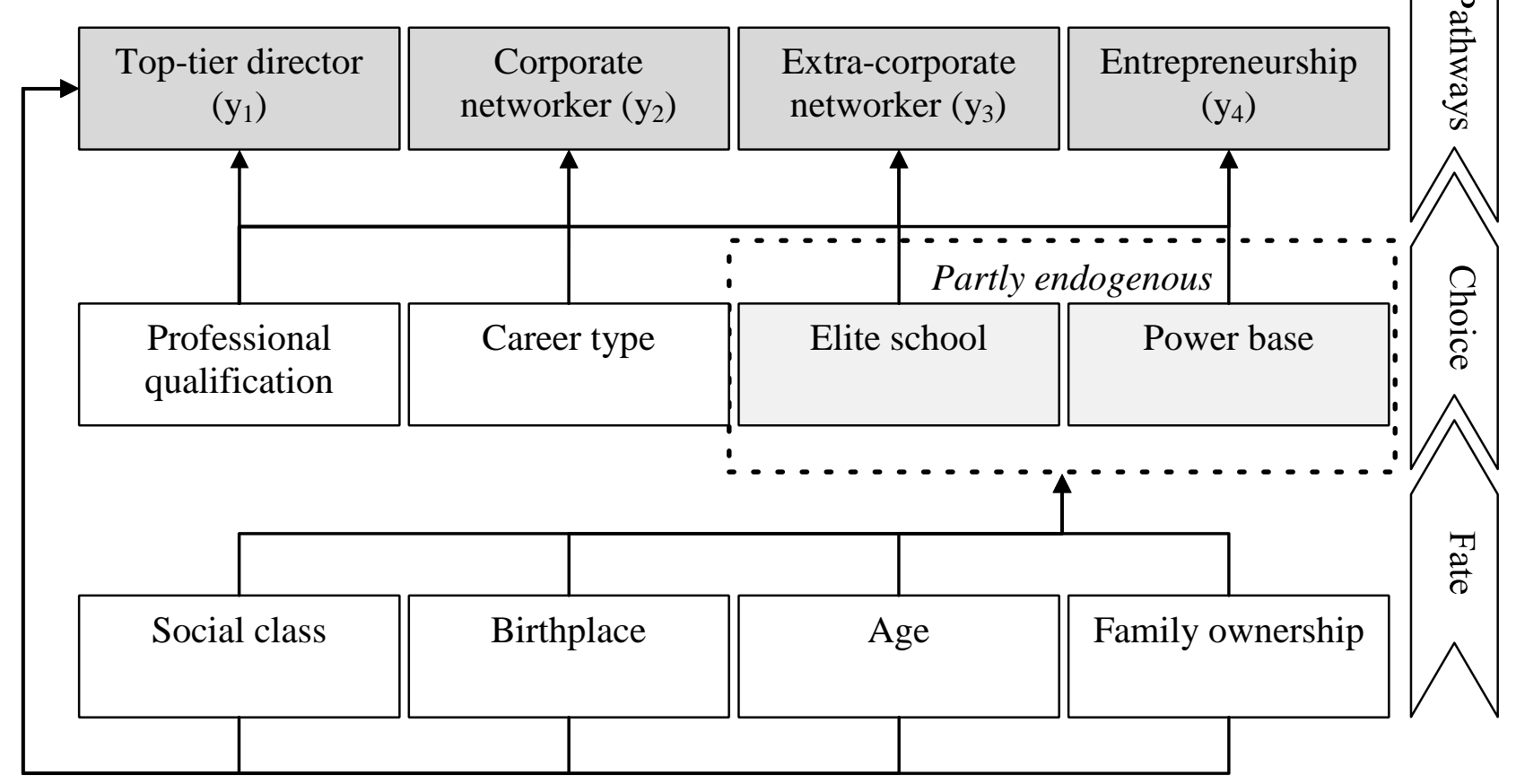


Figure 2: Dynamic model transition probabilities and partial impacts

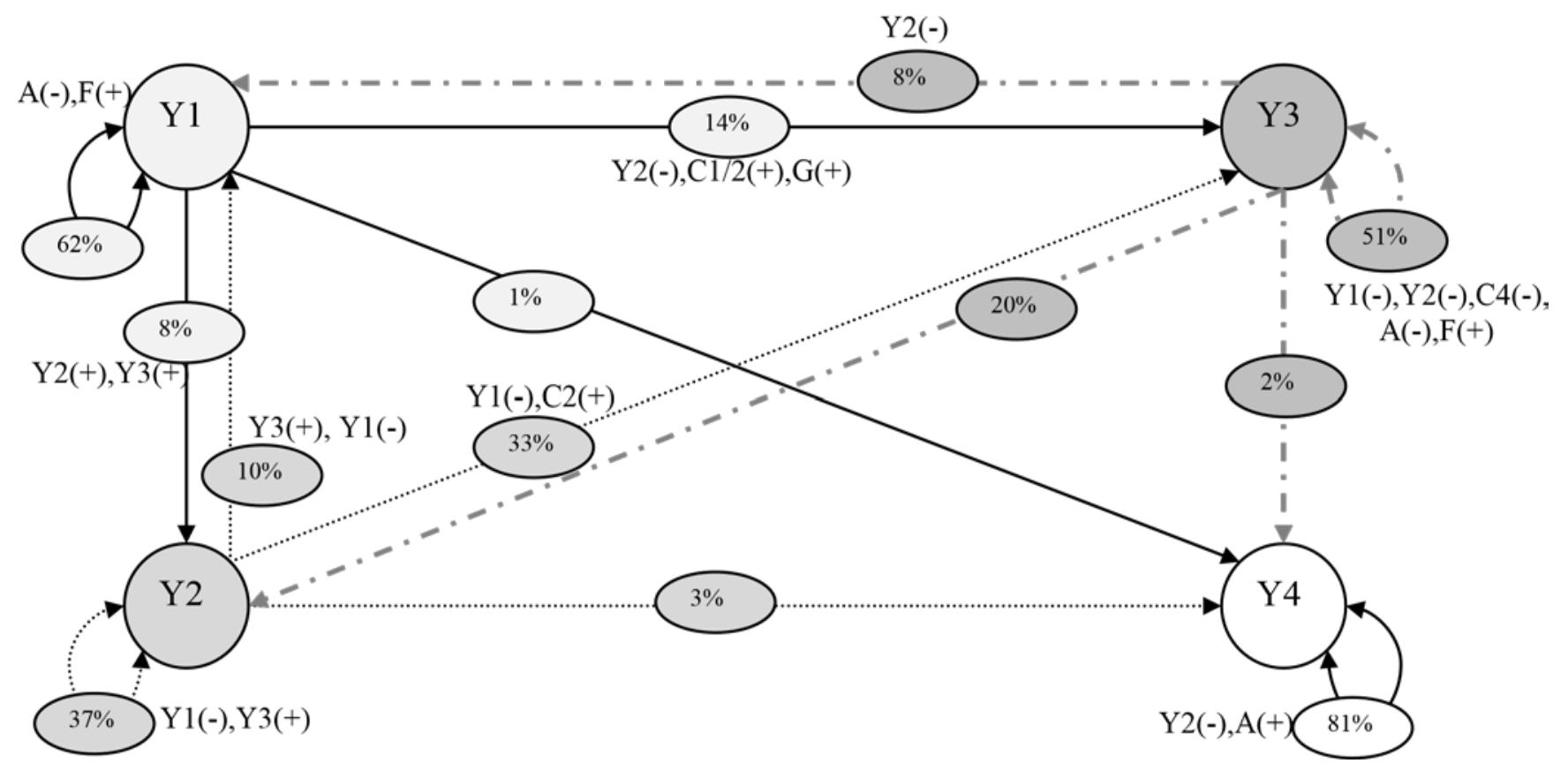


Figure 3: Pathway frequencies by social class

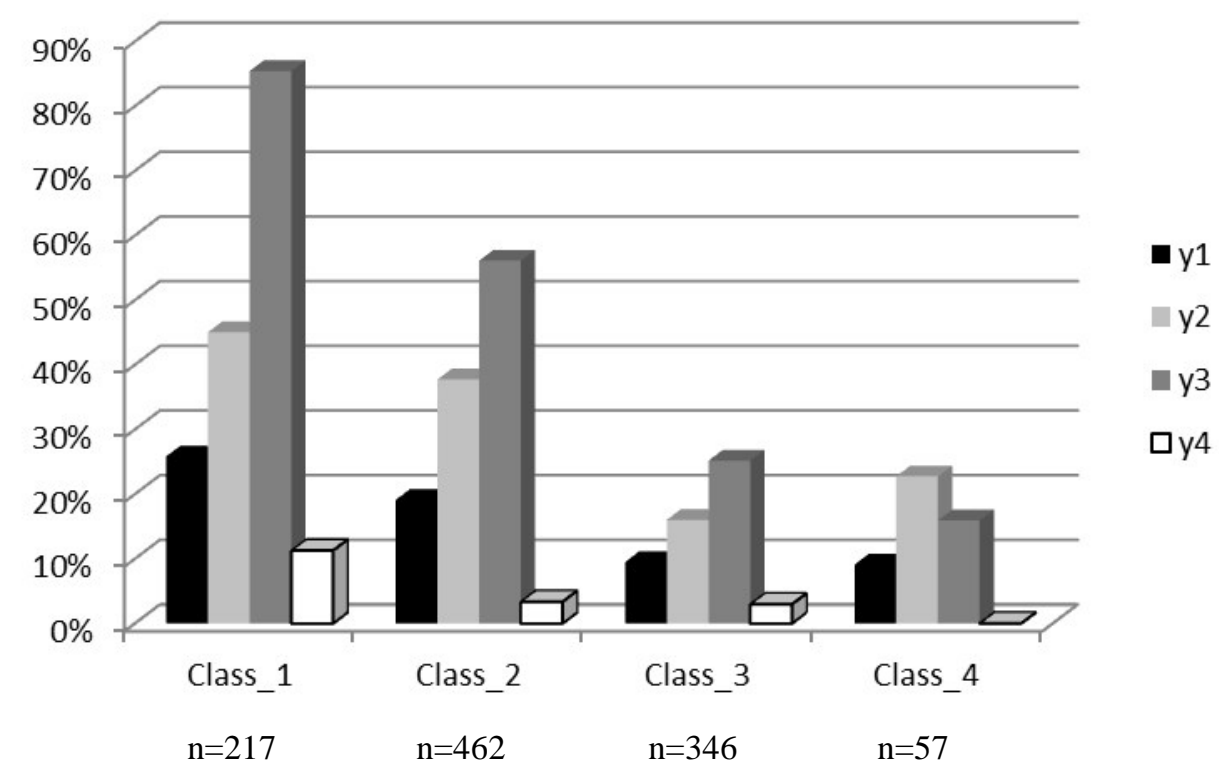


Appendix: Definitions for variables

\begin{tabular}{|c|c|c|}
\hline Variable & Name & Type of variable \\
\hline \multicolumn{3}{|c|}{ 1. Pathways to power } \\
\hline $\mathrm{y} 1$ & $\begin{array}{l}\text { Top-tier executive (CEO or Executive } \\
\text { Chairman) }\end{array}$ & Dummy variable \\
\hline $\mathrm{y}_{2}$ & $\begin{array}{l}\text { Corporate networkers having at least two } \\
\text { directorships of top } 100 \text { companies or one } \\
\text { plus at least two other company } \\
\text { directorships. }\end{array}$ & Dummy variable \\
\hline $\begin{array}{l}3 \\
\end{array}$ & $\begin{array}{l}\text { Membership of two or more extra-corporate } \\
\text { boards }\end{array}$ & Dummy variable \\
\hline $\mathrm{y} 4$ & Company founder retaining $\geq 25 \%$ of equity & Dummy variable \\
\hline \multicolumn{3}{|c|}{ 2. Variables of choice } \\
\hline eliteschl & Elite school & Dummy variable \\
\hline elitehe & Elite higher education & Dummy variable \\
\hline $\begin{array}{l}\text { dis_no, } \\
\text { dis_ahss, } \\
\text { dis_bea, } \\
\text { dis_lop, } \\
\text { dis_sem }\end{array}$ & $\begin{array}{l}\text { Discipline type in HE: arts, humanities, } \\
\text { social sciences; business, economics, } \\
\text { administration; law and other professions; } \\
\text { science, engineering, mathematics }\end{array}$ & $\begin{array}{l}\text { Categorical (nominal } \\
\text { variable) }\end{array}$ \\
\hline $\begin{array}{l}\text { qual_no, } \\
\text { qual_fd, } \\
\text { qual_hd, } \\
\text { qual_phd, }\end{array}$ & $\begin{array}{l}\text { Highest level in HE: none; first degree; } \\
\text { higher degree; doctorate excluding honorary } \\
\text { degrees }\end{array}$ & Ordinal variable \\
\hline profqual & $\begin{array}{l}\text { Recognized professional qualification: yes, } \\
\text { no, or not known }\end{array}$ & Dummy variable \\
\hline $\begin{array}{l}\text { pqtype_af, } \\
\text { pqtype_ag, } \\
\text { pqtype_bi, } \\
\text { pqtype_et, } \\
\text { pqtype_l, } \\
\text { pqtype_mba }\end{array}$ & $\begin{array}{l}\text { Professional qualification types: accounting, } \\
\text { finance; agrégation; banking, insurance; } \\
\text { engineering, technical; legal; master of } \\
\text { business administration }\end{array}$ & $\begin{array}{l}\text { Categorical (nominal } \\
\text { variable) }\end{array}$ \\
\hline $\begin{array}{l}\text { chevaliers } \\
\text { officiers } \\
\text { commandeurs } \\
\text { grand_off } \\
\text { grand_croix }\end{array}$ & Rank within honours system & Ordinal variable \\
\hline $\begin{array}{l}\text { corps_1, } \\
\text { corps_2, } \\
\text { corps_3, } \\
\text { corps_4, } \\
\text { corps_5 }\end{array}$ & $\begin{array}{l}\text { Grand corps membership: Conseil d’Etat } \\
\text { (1); Corps des Mines (2); Cour des } \\
\text { Comptes (3); Inspection des Finances (4); } \\
\text { Corps des Ponts et Chaussées (5) }\end{array}$ & $\begin{array}{l}\text { Categorical (nominal } \\
\text { variable) }\end{array}$ \\
\hline
\end{tabular}




\begin{tabular}{|l|l|l|}
\hline $\begin{array}{l}\text { type_b, } \\
\text { type_pa_b, } \\
\text { type_p_b }\end{array}$ & $\begin{array}{l}\text { Career types: business; public } \\
\text { administration into business; profession into } \\
\text { business }\end{array}$ & $\begin{array}{l}\text { Categorical (nominal } \\
\text { variable) }\end{array}$ \\
\hline
\end{tabular}

\begin{tabular}{|c|c|c|}
\hline $\begin{array}{l}\text { ACAD } \\
\text { ENT } \\
\text { EST } \\
\text { FIN } \\
\text { GMT } \\
\text { HRM } \\
\text { LAW } \\
\text { M_M } \\
\text { OWN } \\
\text { PAD }\end{array}$ & $\begin{array}{l}\text { Career platforms: academic; entrepreneur; } \\
\text { engineering, scientific, technical; financial; } \\
\text { general, operations management; personnel; } \\
\text { law; media, sales, marketing; inherited } \\
\text { ownership; public administration }\end{array}$ & $\begin{array}{l}\text { Categorical (nominal } \\
\text { variable) }\end{array}$ \\
\hline tyear & $\begin{array}{l}\text { Year first joined top } 100 \text { French company } \\
\text { main board }\end{array}$ & Continuous variable \\
\hline tage & $\begin{array}{l}\text { Age first joined top } 100 \text { French company } \\
\text { main board }\end{array}$ & Continuous variable \\
\hline t98 & $\begin{array}{l}\text { Number of top } 100 \text { French company } \\
\text { directorships in } 1998\end{array}$ & Continuous variable \\
\hline oth98 & $\begin{array}{l}\text { Number of non-top } 100 \text { French company } \\
\text { directorships in } 1998\end{array}$ & Continuous variable \\
\hline t04 & $\begin{array}{l}\text { Number of top } 100 \text { French company } \\
\text { directorships in } 2004\end{array}$ & Continuous variable \\
\hline oth04 & $\begin{array}{l}\text { Number of non-top } 100 \text { French company } \\
\text { directorships in } 2004\end{array}$ & Continuous variable \\
\hline $\begin{array}{l}\text { pb_ac, } \\
\text { pb_bf, } \\
\text { pb_b, } \\
\text { pb_ft, } \\
\text { pb_l, } \\
\text { pb_s }\end{array}$ & $\begin{array}{l}\text { Power base: academia; banking, finance; } \\
\text { business; family trust; law; state }\end{array}$ & $\begin{array}{l}\text { Categorical (nominal } \\
\text { variable) }\end{array}$ \\
\hline exnet & $\begin{array}{l}\text { Number of extra-corporate board or } \\
\text { commission memberships }\end{array}$ & Continuous variable \\
\hline cbd & Charity board & Dummy variable \\
\hline pbody & $\begin{array}{l}\text { Membership of public body or significant } \\
\text { political role }\end{array}$ & Dummy variable \\
\hline bassoc & $\begin{array}{l}\text { Board of business, trade or professional } \\
\text { association }\end{array}$ & Dummy variable \\
\hline edbd & Board of HE or research institution & Dummy variable \\
\hline asbd & Board of top sports or cultural organization & Dummy variable \\
\hline
\end{tabular}




\begin{tabular}{|l|l|l|}
\hline con_no & $\begin{array}{l}\text { Highest total number of corporate and extra- } \\
\text { corporate board memberships in 1998 or } \\
\text { 2004 }\end{array}$ & Continuous variable \\
\hline con_span & $\begin{array}{l}\text { Number of life-worlds involved in at } \\
\text { highest level from executive director, } \\
\text { nonexecutive director, public or political } \\
\text { body, business association, charitable } \\
\text { foundation, education or research, arts or } \\
\text { sports }\end{array}$ & Continuous variable \\
\hline 3. Variables of fate & $\begin{array}{l}\text { Four categories and } \\
\text { class_1 to } \\
\text { class_4 }\end{array}$ & $\begin{array}{l}\text { Social class } \\
\text { dummy variables }\end{array}$ \\
\hline h_gender & Gender & $\begin{array}{l}\text { Dummy variable: } 1 \text { for } \\
\text { males and 0 for females }\end{array}$ \\
\hline h_region & Birthplace & $\begin{array}{l}\text { Dummy variable: } 1 \text { if } \\
\text { born in Paris and 0 } \\
\text { otherwise }\end{array}$ \\
\hline age98 & Age & $\begin{array}{l}\text { Continuous variable in } \\
\text { years }\end{array}$ \\
\hline h_afil & Nationality & $\begin{array}{l}\text { Dummy variable: } 1 \text { for } \\
\text { French nationals and 0 } \\
\text { for others }\end{array}$ \\
\hline
\end{tabular}




\section{Author biographies}

Mairi Maclean is Professor of International Management and Organisation Studies at the University of Exeter Business School, where she is Director of Research. Her research interests include international business elites and elite power from a Bourdieusian perspective, entrepreneurship and philanthropy, history and strategy, and comparative organisation studies. She is the author of four books, and editor of a further four. These include Business Elites and Corporate Governance in France and the UK (Palgrave Macmillan, 2006), written with Charles Harvey and Jon Press. Recent publications include contributions to Organization Studies, Human Relations, Management Learning, Business History and Business History Review.

Charles Harvey is Pro-Vice-Chancellor and Provost, and Professor of Business History and Strategic Management at Newcastle University. He is author of numerous books and articles in business history and management. He is co-author, with Sydney Finkelstein and Thomas Lawton of Breakout Strategy (McGraw-Hill, 2007). In 2006 he published, with Mairi Maclean and Jon Press, Business Elites and Corporate Governance in France and the UK (Palgrave Macmillan), a path-breaking study of the exercise of power within two very different national business systems. Recent publications include contributions to the Journal of Management Studies, Human Relations, Organization Studies, Business History, and Business History Review.

Gerhard Kling is Senior Lecturer in Finance at the School of Management, University of Southampton. He received his $\mathrm{PhD}$ in economics from the University of Tuebingen and was awarded the Dissertation Prize of the International Economic History Association. He has published in the British Journal of Management, International Journal of Research in Marketing and R\&D Management. His current research focuses on corporate governance, statistical and mathematical modelling and corporate finance. 